\title{
A Methodology to Detect and Characterize Uplift Phenomena in Urban Areas Using Sentinel-1 Data
}

\author{
Roberta Bonì ${ }^{1, *}$ (D), Alberto Bosino ${ }^{1}$, Claudia Meisina ${ }^{1}$, Alessandro Novellino ${ }^{2}$, Luke Bateson ${ }^{2}$ \\ and Harry McCormack ${ }^{3}$ \\ 1 Department of Earth and Environmental Sciences, University of Pavia, Via Ferrata 1, 27100 Pavia, Italy; \\ alberto.bosino01@universitadipavia.it (A.B.); claudia.meisina@unipv.it (C.M.) \\ 2 British Geological Survey, Natural Environment Research Council, Nicker Hill, Keyworth, \\ Nottinghamshire NG12 5GG, UK; alessn@bgs.ac.uk (A.N.); lbateson@bgs.ac.uk (L.B.) \\ 3 Compagnie Générale de Géophysique (CGG), NPA Satellite Mapping, Crockham Park, Edenbridge, \\ Kent TN8 6SR, UK; harry.mccormack@cgg.com \\ * Correspondence: roberta.boni01@universitadipavia.it; Tel.: +39-03-8298-5842
}

Received: 6 February 2018; Accepted: 12 April 2018; Published: 14 April 2018

\begin{abstract}
This paper presents a methodology to exploit the Persistent Scatterer Interferometry (PSI) time series acquired by Sentinel-1 sensors for the detection and characterization of uplift phenomena in urban areas. The methodology has been applied to the Tower Hamlets Council area of London (United Kingdom) using Sentinel-1 data covering the period 2015-2017. The test area is a representative high-urbanized site affected by geohazards due to natural processes such as compaction of recent deposits, and also anthropogenic causes due to groundwater management and engineering works. The methodology has allowed the detection and characterization of a $5 \mathrm{~km}^{2}$ area recording average uplift rates of $7 \mathrm{~mm}$ /year and a maximum rate of $18 \mathrm{~mm} /$ year in the period May 2015-March 2017. Furthermore, the analysis of the Sentinel-1 time series highlights that starting from August 2016 uplift rates began to decrease. A comparison between the uplift rates and urban developments as well as geological, geotechnical, and hydrogeological factors suggests that the ground displacements occur in a particular geological context and are mainly attributed to the swelling of clayey soils. The detected uplift could be attributed to a transient effect of the groundwater rebound after completion of dewatering works for the recent underground constructions.
\end{abstract}

Keywords: Persistent Scatterer Interferometry (PSI); Sentinel-1; uplift; expansive soils; dewatering; London

\section{Introduction}

Ground displacements can be evidence of several processes of natural origin such as swelling/shrinkage of expansive soils, compaction of recent deposits, tectonic displacements associated to the occurrence of earthquakes or long-term tectonic movements and anthropogenic causes such as pumping-induced aquifer-system compaction [1]. In many instances, the movements are due to the interactions of multi-driving factors that act at various spatial and temporal scales [2]. Furthermore, ground motion can imply surface deformation with 3D displacement components, negative and positive vertical movements and/or horizontal (E-W) movements. Negative displacement corresponds to lowering of the earth surface named land subsidence meanwhile positive displacement is the uplift of the earth surface.

Uplift phenomena are less common and less studied than land subsidence. Positive movements (uplift) can occur as a result of various natural and human causes; for example, swelling of clay soils [3], fault effects [4], and water rebound in mining areas [5,6]. Uplift phenomena can lead to 
various environmental and engineering problems such as springs of polluted water [7] and damage to building foundations [8,9].

In the United Kingdom (UK), shrinking and swelling of clay lithologies represents one of the most damaging geohazards, costing the economy an estimated $£ 3$ billion over the past 10 years as reported by the Association of British Insurers [10]. Accordingly, the capability to detect and quantify the ground displacement of structures and infrastructure at regional and local scale would be a cost-effective tool that offers great value to insurance companies and government institutions.

Persistent Scatterer Interferometry (PSI) is a powerful remote sensing tool, capable of mapping displacements over wide areas at very high spatial resolutions. The technique is based on the processing of multiple interferograms derived from a large set of Synthetic Aperture Radar (SAR) images to obtain displacement time series, along the line of sight (LOS) of the satellite, of radar targets on the earth surface [11-13].

Several studies report on PSI applications for urban deformation monitoring such as the study of displacement time series of buildings, roads, railways, dams, and tunnels [14-22].

London is a megacity of the United Kingdom experiencing an increasing density of structures and infrastructure such as transport tunnels, requiring dewatering schemes to control groundwater during their construction [23,24]. Satellite-based data were previously used to characterize ground displacements in London. Aldiss et al. [25] used ERS and ENVISAT collected between March 1997 and December 2005 to carry out a geological interpretation of the subsidence and uplift trend. Cigna et al. [26] used ERS and ENVISAT covering the time intervals 1992-2000 and 2002-2010 to delineate the boundaries of the geohazards in London within the framework of the European Commission FP7-SPACE project PanGeo. Bateson et al. [27] used the satellite-based data covering the period 1997-2005 to validate the results of the modelled subsidence due to groundwater abstraction for the Merton area of south-west London. Bonì et al. [28] exploited the ERS and ENVISAT covering the time intervals 1992-2000 and 2002-2010 to analyze the ground motion due to the groundwater level changes in London. More recently, high-resolution PSI data from the COSMO-SkyMed constellation has been used to study the effect of tunnel-induced subsidence damage assessment [29].

In this paper, new Sentinel-1 SAR data are used to measure the ongoing displacements in London covering the period from 2015 to 2017. The goals of this study are (1) the exploitation of new and freely available Sentinel-1 data to analyze uplift phenomena and (2) the development of a methodology for the geological interpretation of PSI results in urban areas. The developed methodology represents a refinement for uplift investigations using new Sentinel-1 data, of the methodology proposed in Bonì et al. [30] for subsidence studies. The procedure is addressed to overcome limitations, such as the analysis of large data sets, by (i) improving the management and interpretation of dense time series guaranteed by Sentinel-1 (ii) and to provide an insight on the capability to monitor movements during engineering works given by the reduced revisit time (i.e., 6-12 days) of the latest spaceborne sensors.

Urban developments as well as geological, geotechnical, and hydrogeological factors have been compared with the average velocities and the displacement time series to identify the predisposing and triggering factors of the detected ground displacements. The results allow to detect and characterize uplift phenomena after the termination of engineering works such as dewatering process for structures and infrastructure network construction as in the case of Crossrail tunneling in London.

\section{Study Area}

With more than 60,000 boreholes sunk in Greater London alone, the geology of the London Basin has been widely described by Sumbler [31], Ellison et al. [32], and reviewed by Royse et al. [23]. The Basin consists largely of a broad gentle syncline of Mesozoic and Cenozoic units overlapping the Palaeozoic basement, the London Platform, of folded Silurian and foreland Devonian rocks at depths of $\sim 300 \mathrm{~m}$ in central London. The main geological units of relevance are: The Upper Cretaceous Chalk Group, a fine grained and micro-porous limestone up to $400 \mathrm{~m}$ thick which mainly outcrops in the marginal areas of the basin (Figure 1). Unconformably overlying the Chalk is the oldest Paleogene 
deposit, the Thanet Sand Formation, a 30 m coarsening upwards succession of fine grained, sandy-silty terrigenous sediments [32]. Successively, the basin experienced the deposition of the Lambeth Group (LMBE) composed of 20/30 m illite, smectite and montmorillonite dominant clay intercalated with silty and sandy horizons and lenses. During the Eocene the deposition of the Thames Group, comprising the Harwich Formation and, then, London Clay Formation (LC), started in the basin. West of London, the youngest Eocene sediments in the London Basin are preserved: they are predominantly the sands and clay units of the Bracklesham Group.

The subsequent Quaternary deposits (superficial geology) are represented by the river terrace deposits of the Thames River, locally covered by alluvial deposits of the Thames River.

Due to the erosion of much of the overlying deposits, the LC is probably the most well-known of the units present in the London Basin with a significant influence on London's infrastructure: its widespread presence beneath much of central London, with a thickness between $90 \mathrm{~m}$ in the west and to $150 \mathrm{~m}$ in the east [33] and relatively homogeneous structure makes it a near perfect tunneling medium, thus, facilitating the development of the London Underground [23].

Nevertheless, spatially widespread illite/smectite clay minerals in the LC are particularly susceptible to seasonal processes of shrinking and swelling, potentially damaging buildings and infrastructure [34,35], and therefore represent a major concern for the insurance industry.
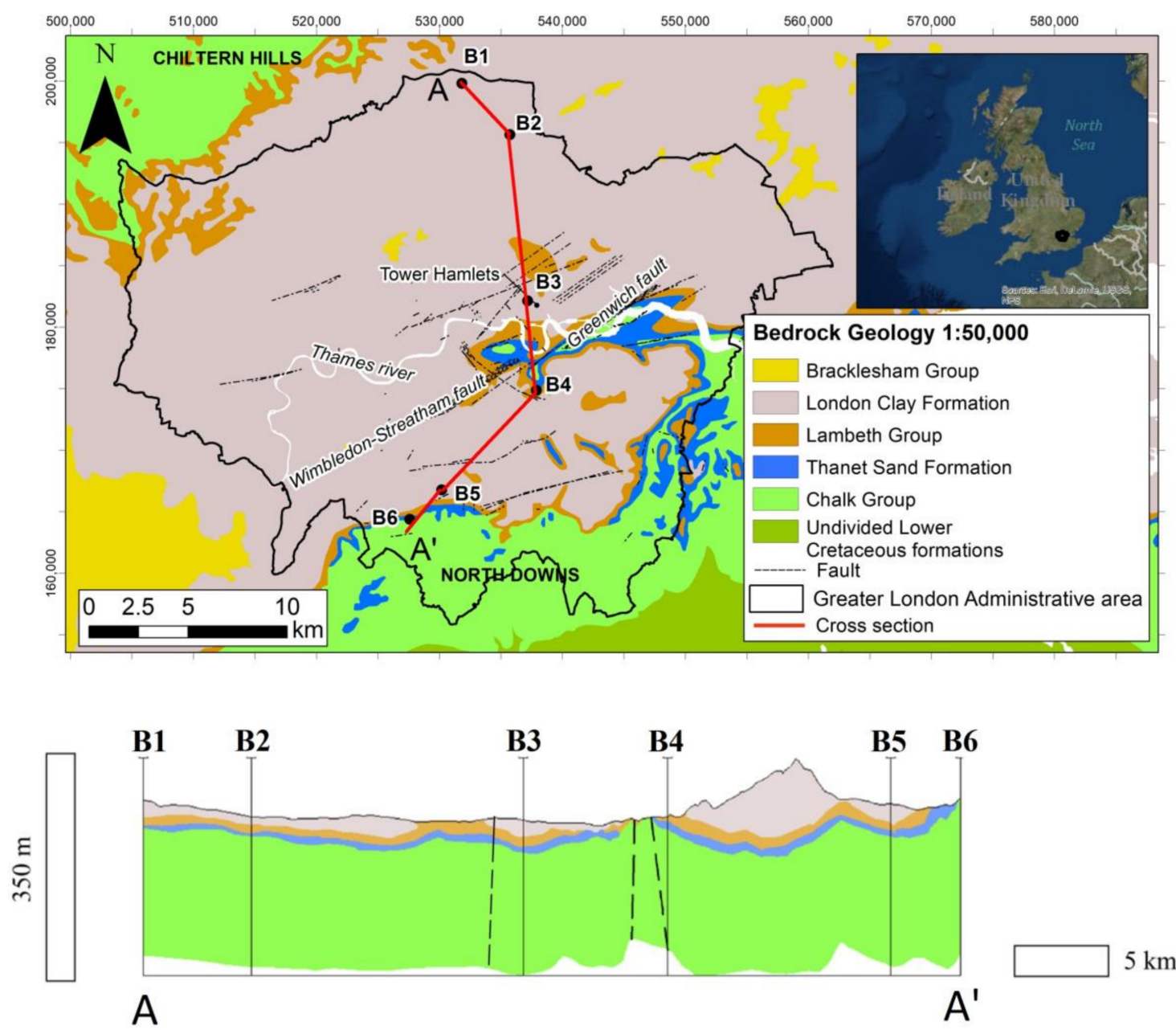

Figure 1. Location (sources: Esri, DeLorme, USGS, NPS) and geological map of London based upon the 1:50,000 bedrock geology, with the permission of the British Geological Survey. All rights reserved. British National Grid. Projection: Transverse Mercator. Datum: OSGB 1936. The geological cross section A-A' is also reported (modified from [28]). 
The main aquifer of the Basin is represented by the Chalk Group. This is characterized by a primary and secondary porosity related to the matrix and the fracturing network, respectively [36-38]. The primary porosity of these rocks is about 35\% [39] but the average conductivity is just about $0.001 \mathrm{~m} /$ day [40]. The basin is marked by several faults that act like a barrier or conduits for the groundwater flow [41,42]. The Chalk outcrops in the northern and southern part of the Basin where it is directly recharged by the rainfall infiltrations. In the central area of the Basin, the overlying Palaeogene formations confine the aquifer. Whereas the lithological variability of Palaeogene deposits leads to hydrogeological heterogeneity, these units do not form principle aquifers. Where sand-rich horizons are present in the Paleogene deposits (Thanet Formation and Lambeth Group), significant quantities of groundwater can be contained. The hydraulic continuity between the Chalk and Thanet Sands may be limited in places, and some continuity with the Lambeth Group depending on the clay and sand content [41]. Therefore, Chalk-Thanet Sands (deep aquifer) and Lambeth Group-Harwich Formation (intermediate aquifer) are regarded as separate aquifers for resource management [41]. The sand unit of Lambeth Group and Harwich Formation represents the intermediate aquifer that it encloses in the top and bottom by the clayey units of the London Clay and the Lambeth Group, respectively.

River Terrace Deposits (RTD) and Made Ground (MG) form a minor shallow aquifer, separated from deeper aquifers by clay layers.

The groundwater level (GWL) lowering across the London Basin mainly started in the mid-1850s with a progressive increase in abstraction from the Chalk aquifer. This abstraction became unsustainable leading to unconfined conditions in about 1940 and started to rise again after the mid-1970s [41,42]. In order to contrast this local groundwater variation, that can lead to serious effects on both building foundations and shallow structures such as the London Underground etc., the General Aquifer Research, Development and Investigation Team (GARDIT) strategy was developed by Thames Water, Environment Agency and London Underground and as a result, an observation borehole network within the Basin was established in order to control and manage the GWL in the London Basin [41,42]. In this area, more than 20 major tunneling projects started since the 1980s, the latest being: Pimlico and Wandsworth to Wimbledon cable tunnel (1992-1995), Jubilee Line Extension (1993-1999), Channel Tunnel Rail Link (2001-2006) and the National Grid power tunnels (2011 to present).

\section{Data}

A multidisciplinary approach has been implemented in order to carry out a comprehensive study of the investigated phenomena, by using satellite radar interferometric data and different information contained in geological, geotechnical, hydrogeological and buildings database.

\subsection{PSI Data}

The study has been performed using 79 SAR images acquired by Sentinel-1A/B satellites on the descending pass on track 201. The images were acquired from May 2015 to March 2017 with a nominal revisit cycle of $6 / 12$ days. Processing was carried out using the GAMMA software-and, in particular, the Interferometric Point Target Analysis-IPTA package [43]. IPTA allows millimetric displacement measurements to be made using individual, highly reflective terrain-features that provide a persistent response throughout the multi-temporal dataset being analyzed. These 'persistent scatterers' (PS) generally correspond to parts of man-made structures such as buildings, bridges, pylons, etc., or hard, rocky terrain. A multi-master approach was used with displacement, elevation and thermal expansion coefficients estimated for each PS.

Results are in the satellite line-of-sight and therefore contain a combination of vertical and horizontal displacement components. The line-of-sight is defined by an incidence angle of 34 degrees from nadir and a look orientation of 282 degrees. The processing results show a total of 1,455,921 PS, over a processing area of around $1596 \mathrm{~km}^{2}$, hence the target density amounts to $912 \mathrm{PS} / \mathrm{km}^{2}$ (Figure 2). 


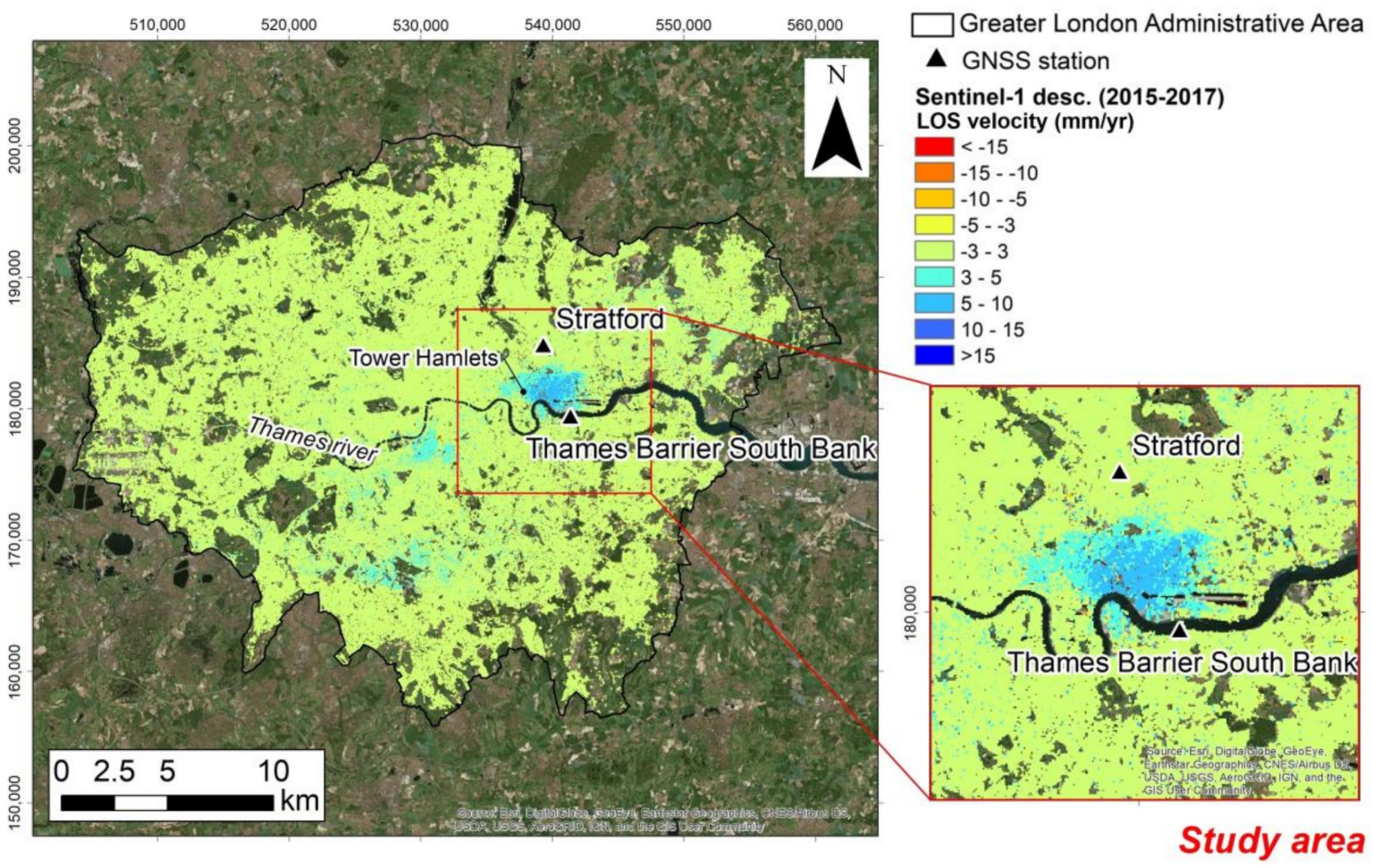

Figure 2. Average line of sight (LOS) velocity measured by the use of Sentinel-1 data during the period 2015 to 2017 across the study area. The location of the GNSS station is also reported.

The Sentinel-1 dataset covers a limited observation period, thus, the historical ascending ERS- $1 / 2$ and descending ENVISAT data, from 1992 to 2000 and from 2002 to 2010 [26,28], respectively, have been also analyzed for the characterization of the local scale ground instability (study area, see the location in Figure 2). PSI ground motion data acquired by ERS1/2 and ENVISAT data, are characterized by nominal repeat cycle of 35 days and were also processed using the GAMMA SAR and Interferometry software and, in particular, the IPTA algorithm [43]. This allows an investigation into the evolution of displacement from 1992 through to the current day.

\subsection{Geological, Groundwater Level and Buildings Database}

Different datasets have been considered to analyze the predisposing and triggering factors of ground motion in London. The exploited databases are described as follows.

- Groundhog Desktop from the British Geological Survey (BGS)

Groundhog Desktop is a free-to-use software tool for visualizing and interpreting a range of geological and environmental data such as boreholes, water levels, geo-technical and geo-chemical measurements, geological maps, conceptual models, and cross-sections [44]. The database contains more than 1,300,000 records of boreholes, shafts, and wells from all forms of drilling and site investigation work available in Great Britain. This database has been used to estimate the thickness of the clayey deposits.

- National Geotechnical Properties Database (NGPD) from BGS

The NGPD holds geotechnical information extracted from site investigation records provided by clients; consultants and contractors, and from field and, secondarily, from laboratory test results carried out by the BGS [45]. For each sample, the location, the lithology, the depth, and the geotechnical characteristics are documented. The Swelling Pressure of the clayey layer has been analyzed using this database. 


\section{- GeoSure from BGS}

GeoSure identifies and classifies the susceptibility connected to areas of potential natural ground movement in Great Britain. The database provides information on the Volume Change Potential (VCP) and Volume Change Potential Range of the shrinking-swelling formations in three-dimensional space; at intervals down to $20 \mathrm{~m}$ in Greater London [46]. The VCP values are based on the Modify plasticity Index (Ip') proposed in the Building Research Establishment Digest 240 [46].

- Groundwater level data from Environment Agency (EA)

The EA maintains an extensive network of groundwater level observation boreholes within and outside the London Basin. Time series data for groundwater levels have been made available from the Environment Agency's WISKI database and plotted as water level in m AOD (above ordnance datum; UK sea level measurement).

- Building height map from Emu Analytics

The online database [47] shows the height of each buildings for England's largest urban areas, based upon the EA's LiDAR data up to 2015.

- Building age map from Consumer Data Research Centre

The database [48] shows, for the major cities of England and Wales, the age of constructions of residential structures present in it. The dwelling age data is supplied grouped in approximately ten-year age bands starting from 1900 with a count of the number of houses in each band plus a Pre-1900 band that groups all the previous buildings.

\section{Methodology}

In this section, the procedure to analyze uplift phenomena in urban areas by exploiting the new Sentinel-1 data is presented refining the one discussed in Bonì et al. (2016) [30] for subsidence studies. The procedure consists of three main phases (Figure 3). In the first phase, the displacement time series (TS) and the average velocity accuracy assessment is performed. In the second phase, different statistical tests are applied in order to find the spatio-temporal pattern of the principal components of movement, and the kinematic model of the targets. Finally, the third step consists of the mechanism recognition of the ground motion areas. Therefore, the integration of satellite data with geological, geotechnical, hydrogeological, urbanization and construction processes data is considered in order to investigate the causes of ground motion processes. The phases of the methodology are described in detail in the following subparagraphs.

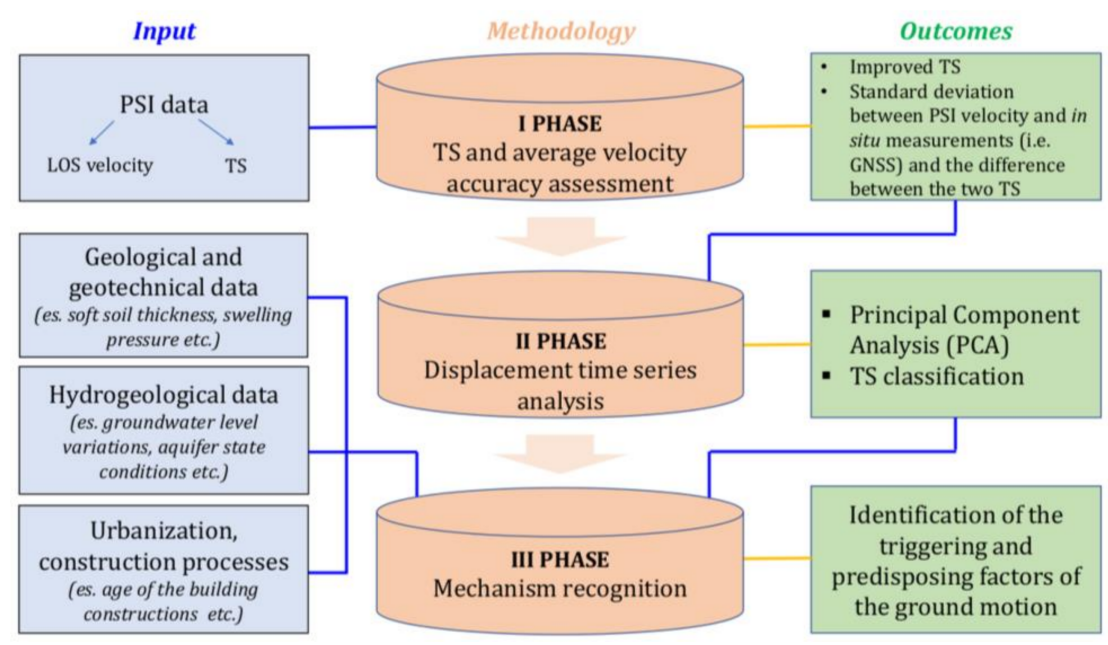

Figure 3. Flowchart of the methodological approach to detect and characterize uplift phenomena in urban areas. 


\subsection{Displacement Time Series and Average Velocity Accuracy Assessment}

In order to properly exploit the TS and the average velocities, it is fundamental to take into account that these measurements can be sensitive to uncompensated orbital errors or uncompensated low frequency atmospheric effects [49]. These systematic errors can affect both TS and the average velocities and can be detected as regional trends in the whole dataset [50]. Furthermore, TS are also sensitive to the phase noise, therefore, a post-processing analysis of the PSI data is essential to avoid misinterpretation of unreal ground deformation. A TS check is performed by selecting the most coherent $(>0.9)$ targets with an average LOS velocity in the range $\pm 0.5 \mathrm{~mm}$ /year., where no significant movements are expected. The approach proposed by Notti et al. [51] was applied to correct uncertainty due to regional unreal trends, and anomalous displacement detected on certain dates (i.e., unreal movements at the same time as meteorological events, such as snowfall). Thus, the average TS of the selected targets is extracted and according to the wavelength of the sensor (C-band), a threshold $\pm 5 \mathrm{~mm}$ of displacement along LOS is considered for detecting anomalous dates. The regression line of the average TS of the selected target is computed to investigate if the dataset is affected by regional trend or tilts.

Additionally, TS and the average velocity accuracy assessment is also performed using external data such as measurements acquired by levelling campaigns, inclinometers, or Global Navigation Satellite Systems (GNSS) stations. First, PSI time series and the average velocities are projected along the vertical direction, by dividing them for the cosine of the satellites incidence angle. Then, the average velocity is computed for the period that matches between the two independent techniques. Thus, the standard deviation between the PSI and GNSS average velocity $\left(\delta_{\mathrm{VEL}}\right)$ is estimated. The same procedure is also applied for the displacement time series. In this case, the standard deviation of the difference between the PSI and GNSS time series $\left(\delta_{\mathrm{TS}}\right)$ is computed. If the standard deviation of the PSI and GNSS average velocity and of the difference between the displacement time series is close to the sensitivity of the PSI technique the results can be assumed as consistent.

\subsection{Displacement Time Series Analysis}

PSI techniques allow the measurement of the average velocity and the displacement time series of a huge number of measurement points. The displacement time series are complex to interpret using manual analysis. Indeed, recent studies report some methodologies to overcome limits related to manual and visual analysis of TS [51-54] using automatic or semi-automatic time series analysis. These methodologies support the analysis of large PSI datasets in order to identify areas of interest using the time series trends. Here, two approaches have been implemented: (1) a statistical procedure to find the principal components (PC) of TS and (2) an automatic classification tool for TS based on statistical tests that analyze the variance.

PC analysis has been applied to satellite-based time series by implementing a matrix of PS location versus time [30]. The matrix contains in each column the LOS displacements for each SAR image, and in each row the displacement time series of the targets. The main outcomes are the correlation and covariance matrices, the eigenvalues and eigenvectors, the percent variance that each eigenvalue captures, and the PC score maps. In interpreting the principal components, PC scores and the eigenvectors related to each target are useful for knowing the distribution and the trends of the principal components. Furthermore, scree plots of the percentage of variance explained by each principal component is useful to find the number of significant PC of the dataset.

The second procedure is the TS analysis using the PS-Time program [54], which is a freely downloadable toolbox compiled in MATLAB [54]. The main outcome is the classification of TS in one of three predefined target trends such as uncorrelated (displacement fluctuates erratically over time), linear (linear and constant velocity) and non-linear (changes of the velocity over time and style of deformation that can be quadratic, bilinear, discontinuous with constant velocity and discontinuous with variable velocity) based on a sequence of statistical tests that discriminate different styles of 
ground deformation. Furthermore PS-time program permits the detection of the date (break) where abrupt changes in slope in non-linear TS are recorded.

Then, the outcomes of the two approaches are exploited to enhance the interpretation of the predisposing and triggering factors using cross-comparisons.

\subsection{Mechanism Recognition}

Geological interpretation of satellite data is performed using external data (such as geological, geotechnical, hydrogeological, urbanization and construction process data), by integrating them into a Geographical Information System (GIS). The recognition of the mechanisms is based on cross-comparison of the representative subsoil geological profiles, and the relative displacement time series with multidisciplinary information [14]. Furthermore, the analysis of the breaks and the detection of the deceleration and acceleration periods are fundamental to identify the predisposing and triggering factors.

\section{Results}

\subsection{Displacement Time Series and Average Velocity Accuracy Assessment}

The displacement time series were analyzed as described in 4.1. First, targets characterized by coherence higher than 0.9 and LOS velocity in the range $\pm 0.5 \mathrm{~mm}$ /year were selected. By applying this filter to the whole dataset $14.5 \%$ of PS shows high coherence and low velocity rates. Then, the average displacement of the selected targets has been computed for each SAR scene, to extract the average TS (Figure 4). It is worth noting that Sentinel-1 data are affected by a higher noise than the long-term time series such as acquired by ERS-1/2 and ENVISAT satellites. The reason for this issue is mainly due to the much shorter time span covered by the Sentinel- 1 data ( 2 years) [55].

However, the results show that anomalous LOS displacement at certain date and regional trends are not evident. Therefore, all SAR scenes have been exploited for the following analysis and post-processing corrections were not implemented.

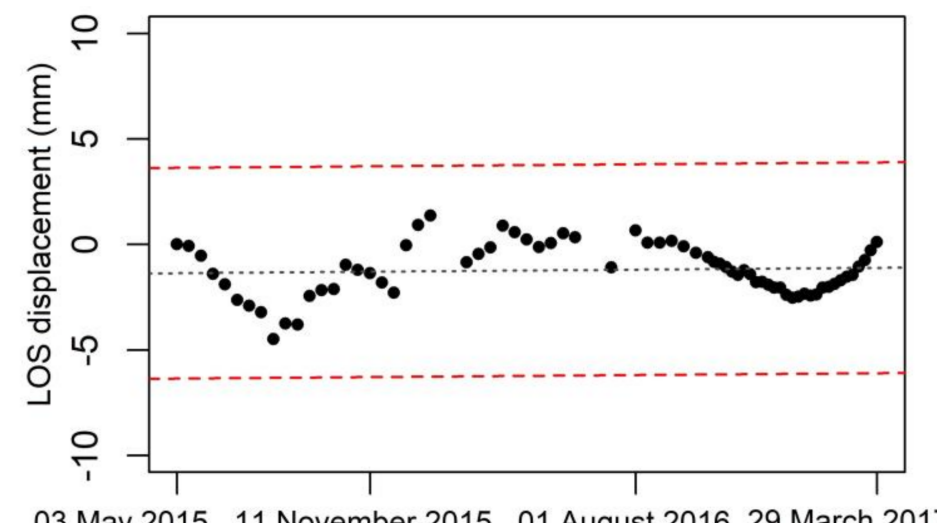

03 May 201511 November 201501 August 201629 March 2017

Figure 4. Average displacement time series (TS) of the targets characterized by coherence higher than 0.9 and LOS velocity in the range $\pm 0.5 \mathrm{~mm}$ /year. The black dotted line represents the regression line of the average TS whereas the red ones are the upper and lower threshold line.

Furthermore, the measurements acquired by two GNSS stations located in London, and available through the British Isles Continuous GNSS Facility (http:/ / www.bigf.ac.uk/), have been exploited (see the location in Figure 2) to obtain a comparison of the displacement time series and the average velocity using independent data. Firstly, LOS displacements TS and average velocities were projected along the vertical direction, by assuming that the displacement is essentially vertical $[25,26]$. This estimation was done dividing the LOS measurements by the cosine of the incidence angle. 
The measurements acquired at the Stratford station (STRA) and Thames Barrier South Bank station (TBSB) were compared with the average velocity and TS of the nearest targets (around 12 and $30 \mathrm{~m}$, respectively) characterized by a value of coherence higher than 0.9 (Figure 5). Also, in this case, TS acquired by the Sentinel-1 sensors are characterized by a higher noise than the measurements acquired by the two GNSS stations for the short total time span covered by this dataset [55]. The standard deviation of the velocity acquired by PSI data and the Stratford station $\left(\delta_{\mathrm{VEL}}\right)$ reaches values of $1.35 \mathrm{~mm} /$ year. While the standard deviation of the difference between the PSI and GNSS time series $\left(\delta_{\mathrm{TS}}\right)$ reaches values of $0.66 \mathrm{~mm}$. The comparison between the PSI data and the measurements acquired at the Thames Barrier South Bank station shows values of $1.34 \mathrm{~mm} /$ year and $1.59 \mathrm{~mm}$ for $\delta_{\mathrm{VEL}}$ and $\delta_{\mathrm{TS}}$; respectively. It is worth noting that the use of only two GNSS stations cannot adequately validate the PSI data at the scale of the basin. However, the results show that at local scale the PSI data are consistent with the displacements and velocities measured by the available GNSS stations. Indeed, the retrieved values for $\delta_{\mathrm{VEL}}$ and $\delta_{\mathrm{TS}}$ are comparable with the values $(1 \mathrm{~mm} /$ year and $5 \mathrm{~mm})$ obtained by previous authors using the C-band sensors [56]. Whereas, a higher accuracy was detected using X-band sensors $(0.5-01 \mathrm{~mm}$ /year and $1 \mathrm{~mm})$ by other authors $[57,58]$.
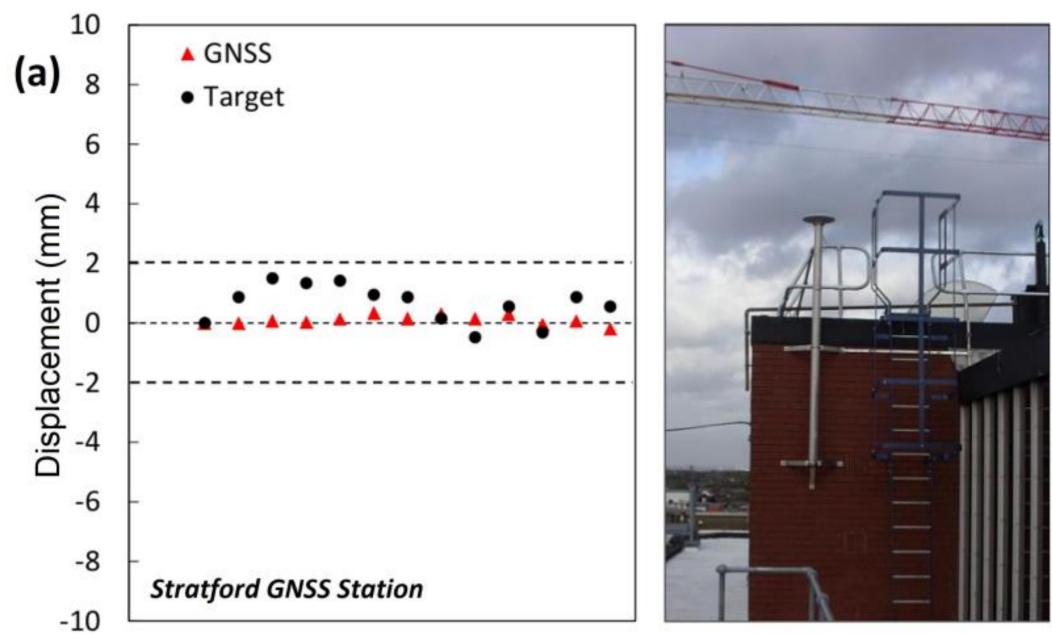

06 April 201505 June 201504 August 201503 October 2015
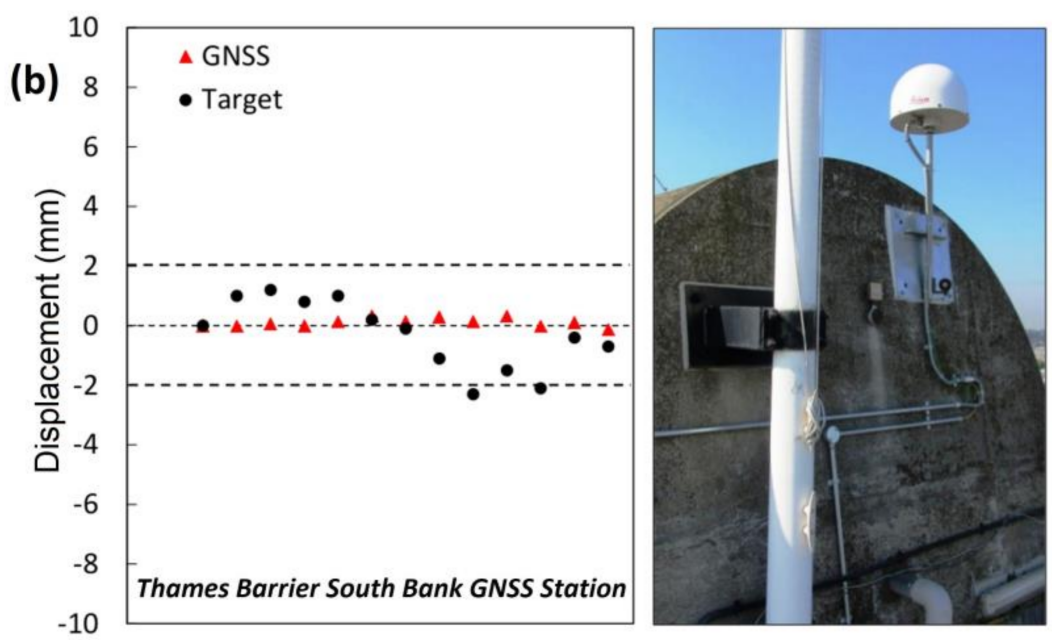

06 April 201505 June 201504 August 201503 October 2015

Figure 5. Comparison between the PSI and GNSS vertical displacement time series. See Figure 2 for the GNSS stations location. The antenna installation images are also reported (available data at http:/ / www.bigf.ac.uk/files/network_maps/script_all_pcsn_30s.html). 


\subsection{Displacement Time Series Analysis}

Following the time series accuracy assessment, TS were analyzed through different automatic statistical procedures; such as the Principal Component Analysis (PCA) and the TS classification in predefined target trends. The first procedure has been performed at large scale (the Greater London administrative area) using TS over the whole dataset, while the second one has been applied using TS at local scale over an area of $206 \mathrm{~km}^{2}$ (study area, see the location in Figure 6). Indeed, even though the average velocity may be useful to detect physical processes characterized by linear trends, the same parameter seems not to be efficient in detecting non-linear and seasonal movements [59]. TS classification was implemented to investigate in detail the study area and was not performed at large scale for the computational load.

Principal Component Analysis approach has been applied using the procedure described in Section 4.2. Principal component analysis was performed using Sentinel-1 data to analyze the spatio-temporal deformation pattern during the period 2017-2017 as previously applied using different SAR data for land subsidence studies [30,53,59]. The results show that the first component of motion (PC1) explains $97.3 \%$ of the variance and $2.54 \%$ is explained by the second component of motion (Figure 6d). The other components are not significant (explained variance lower than $1 \%$ ) and were not considered in the following analysis. Figure 6 shows the spatial distribution of the principal components score units. Positive scores for a PC have a TS trend similar to that of one of the eigenvector time functions, while those with negative scores show a TS trend opposite to that of the eigenvector time function [60]. Indeed, each PC is defined by a linear combination, whose coefficients, termed eigenvectors, are the magnitude of the contribution of each original variable to each PC [60].

The spatial pattern of the PC scores highlights that PC1 mainly affects the southwestern sector of the Greater London administrative area (Figure 6a); while the second component is mainly localized in the southwestern sector (Figure $6 \mathrm{~b}$ ) and in the uplift zone localized in the study area (see insets box in Figure $6 \mathrm{~b}$ ). A visual inspection of the principal components eigenvectors of the dataset covering Greater London administrative area (Figure 6c) highlights that the first component (PC1) corresponds to the long-term linear lowering of the earth's surface, while the second one corresponds to the long-term uplift ground motion with a non-linear trend. The uplift area is characterized by negative scores of the PC1 and high positive score of the second one. Therefore, the TS trend of the uplift phenomena is directly correlated with the PC2 trend. The PCA approach has allowed for the easy detection of not only the uplift but also the non-linear trend of this phenomena characterized by two breaks in the eigenvector time function (Figure $6 c$ ) by analyzing around 1,455,921 PS. Furthermore, the boundaries of the uplift zone have been defined using the approach proposed by Bonì et al., 2016 [53], by using a buffer area of $50 \mathrm{~m}$ around the PS characterized by PC2 score higher than the interquartile range (Figure 10).

TS classification has been applied to investigate in detail the time series trend in the uplifting area. The results of the automatic TS classification show that among the selected targets (around 260,000) in the study area, $74.5 \%$ are classified with a non-linear trend, whereas $1.6 \%$ are classified with a linear trend (Figure $7 \mathrm{a})$. The remaining targets (23.9\%) show uncorrelated time series. The non-linear time series are characterized by a strong non-linearity. Non-linear time series are bilinear trend and mainly, changes in trends in displacement time series were identified at August 2015 and May-August 2016 in the Tower Hamlets area. The results are consistent with the eigenvector of the second component of ground motion detected using the PCA approach. Indeed, by selecting the targets within the uplift zone (see the location in Figure 10) and by computing the average TS (Figure 7b), the break dates are evident. LOS velocity until August 2015 is $-12.86 \mathrm{~mm}$ /year, whereas in the following period an uplift trend with LOS velocity of $8.31 \mathrm{~mm} /$ year is observed. Furthermore, starting in May-August 2016, a deceleration of the movements is detected, with LOS velocity of $1.23 \mathrm{~mm} /$ year.

The results of the analysis highlight that a remarkable ground uplift phenomenon has been detected in an area of $5 \mathrm{~km}^{2}$ with deformation rates ranging from to 6 to $18 \mathrm{~mm}$ /year and the TS 
analysis give insight about acceleration and deceleration of the ground motion during the monitored period (2015-2017).
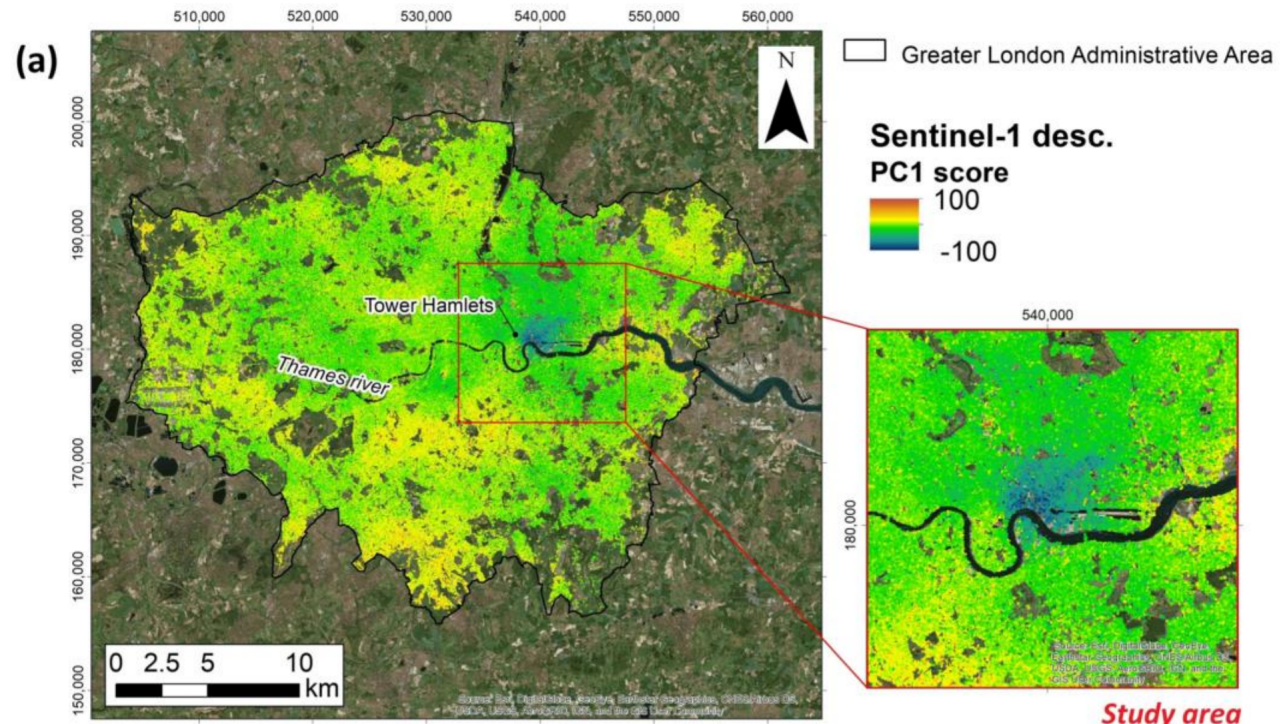

\section{Sentinel-1 desc. \\ PC1 score}

100

$-100$

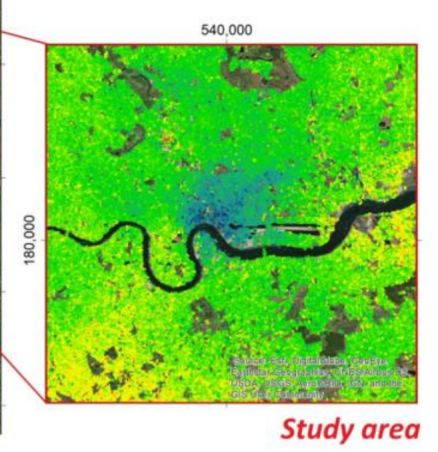

(b)

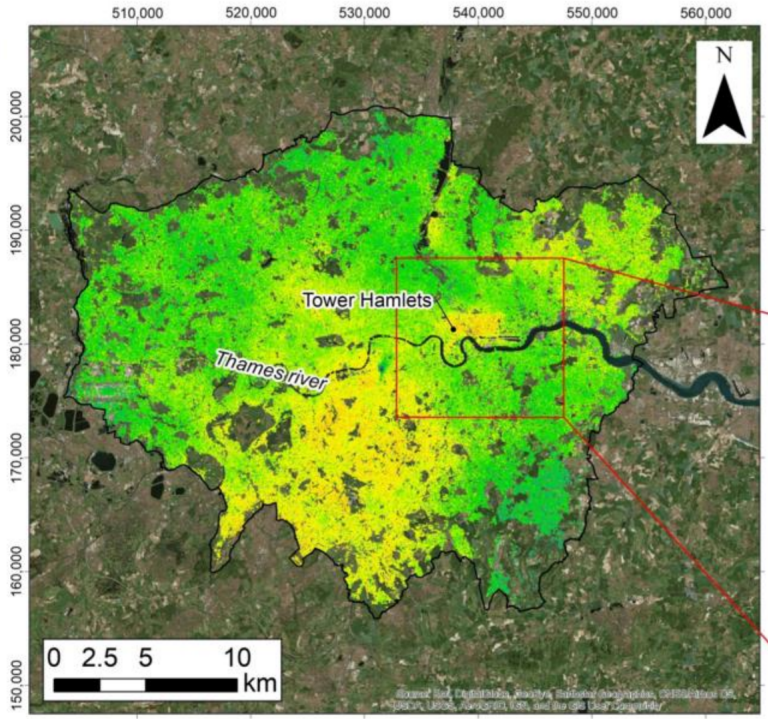

Greater London Administrative Area

Sentinel-1 desc.

PC2 score

30

$-30$
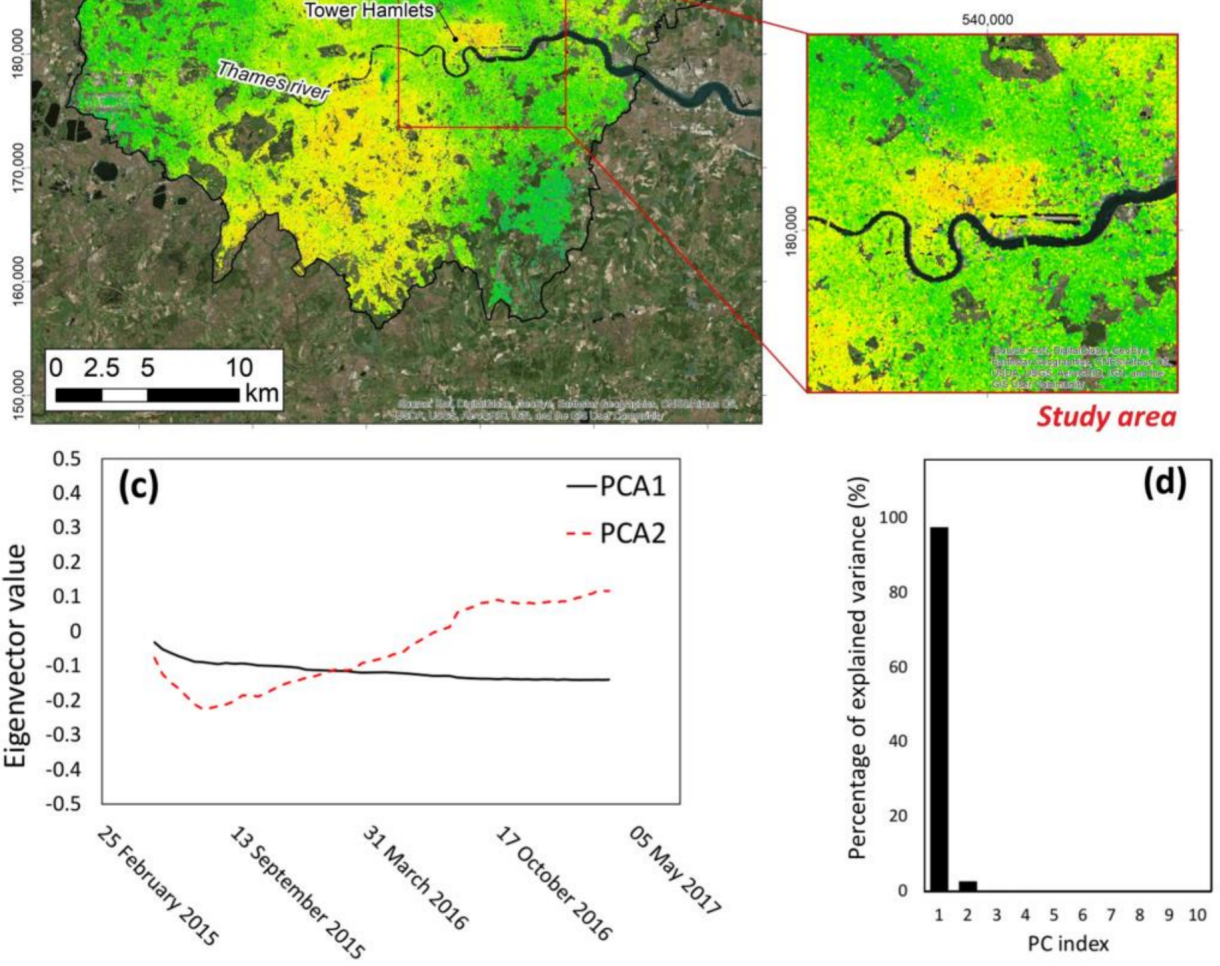

Figure 6. Principal component score maps of the first (a) and second (b) component of motion. Eigenvector value (c) of the principal component (PC) and the percentage of explained variance (d) are also reported. 


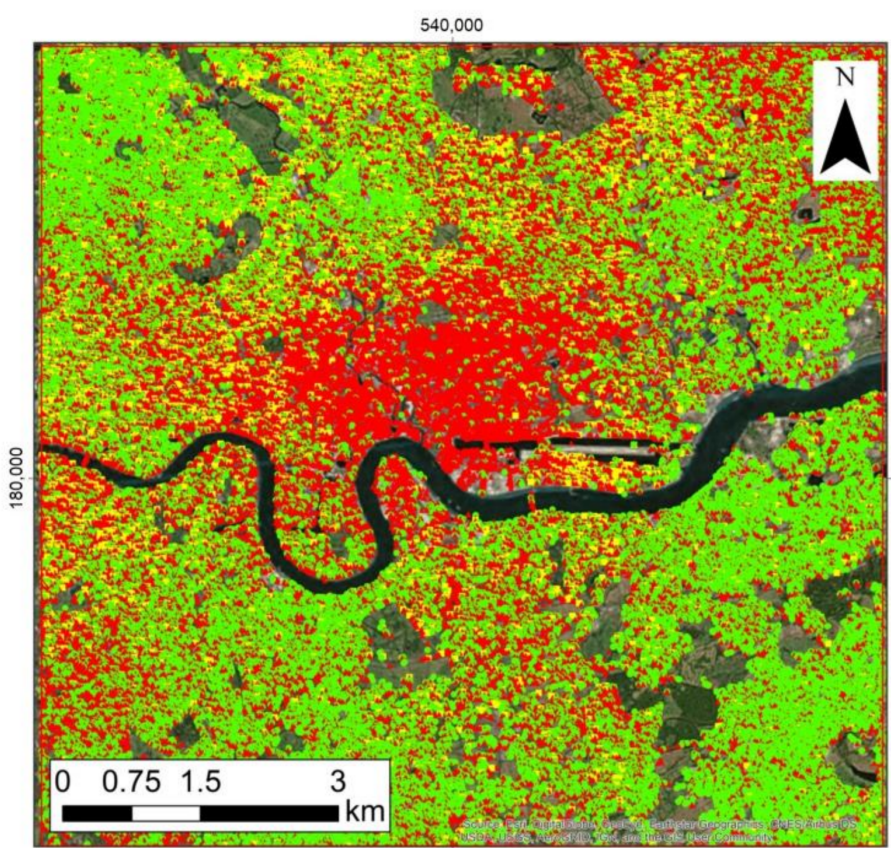

Time series type

(a)

- Uncorrelated

Linear

$\Delta$ Non-Linear
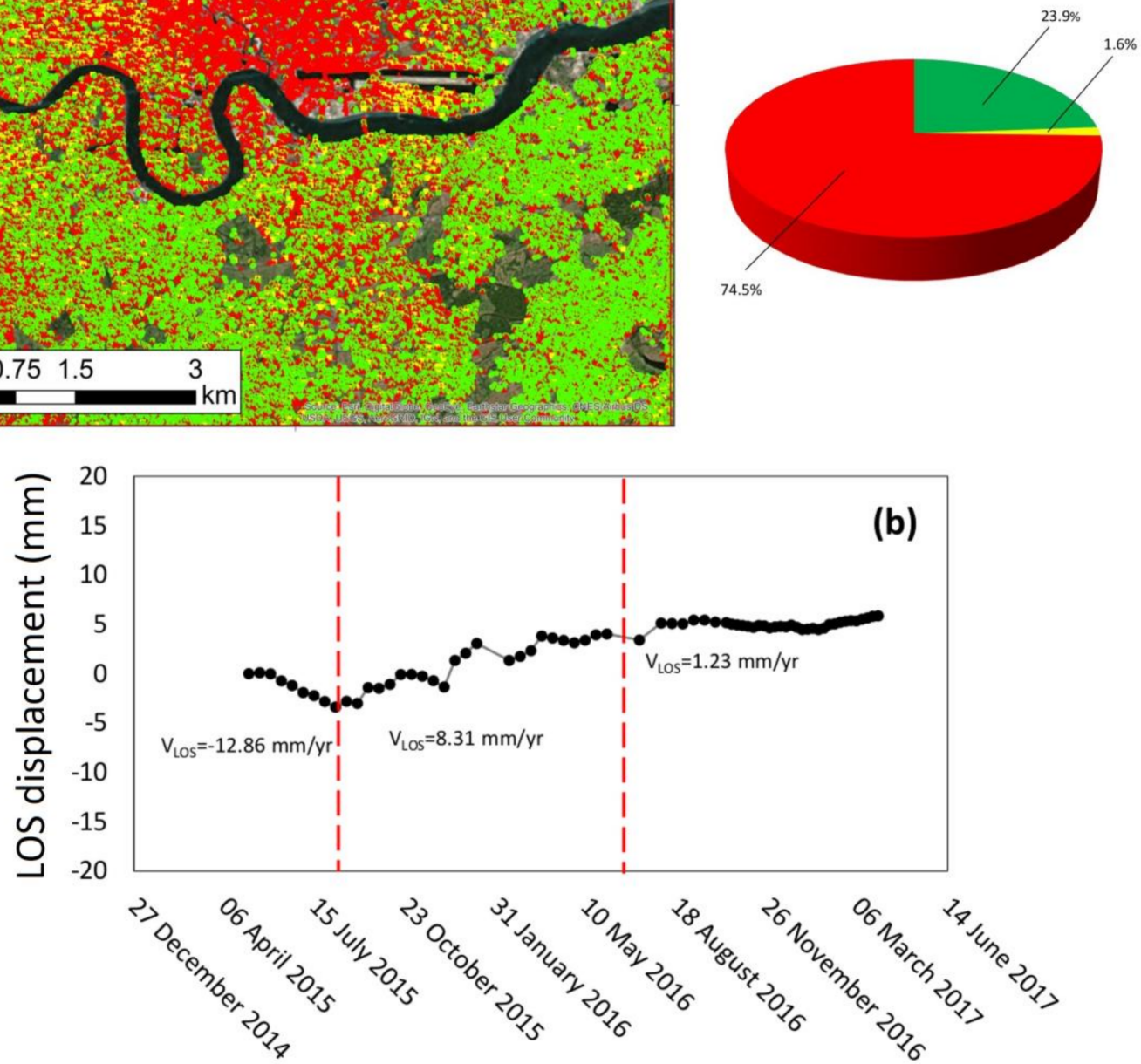

Figure 7. TS trends in the uplift zone (a). Average TS of the non-linear targets located in the uplift zone. The detected breaks (red dotted lines) are also reported (b). See the location of the uplift zone in Figure 10.

\subsection{Mechanism Recognition}

\subsubsection{Analysis the Geological and Geotechnical Factors}

The lithological information of 21 boreholes provided by BGS were exploited to estimate the thickness of the clayey soils in the study area (Figure 8a). First, the thickness of the LC was computed and then, the estimation of the clayey soils was estimated as the total thickness of the clayey soils considering the LC and LMBE (Figure 8d). Furthermore, the average LOS velocity in a $50 \mathrm{~m}$ buffer zone were estimated for each borehole. Considering the thickness of the LC, the comparison between the clayey soils thickness and the LOS velocity show a coefficient of determination $\left(R^{2}\right)$ for the linear regression of 0.56 (Figure 8c). While by considering the clayey layers of the LC and the LMBE, a higher correlation is retrieved showing a coefficient of determination, $\mathrm{R}^{2}$ for the linear regression of 0.75 (Figure 8d). Therefore, the uplift rates are higher when the clayey layers are thicker. 

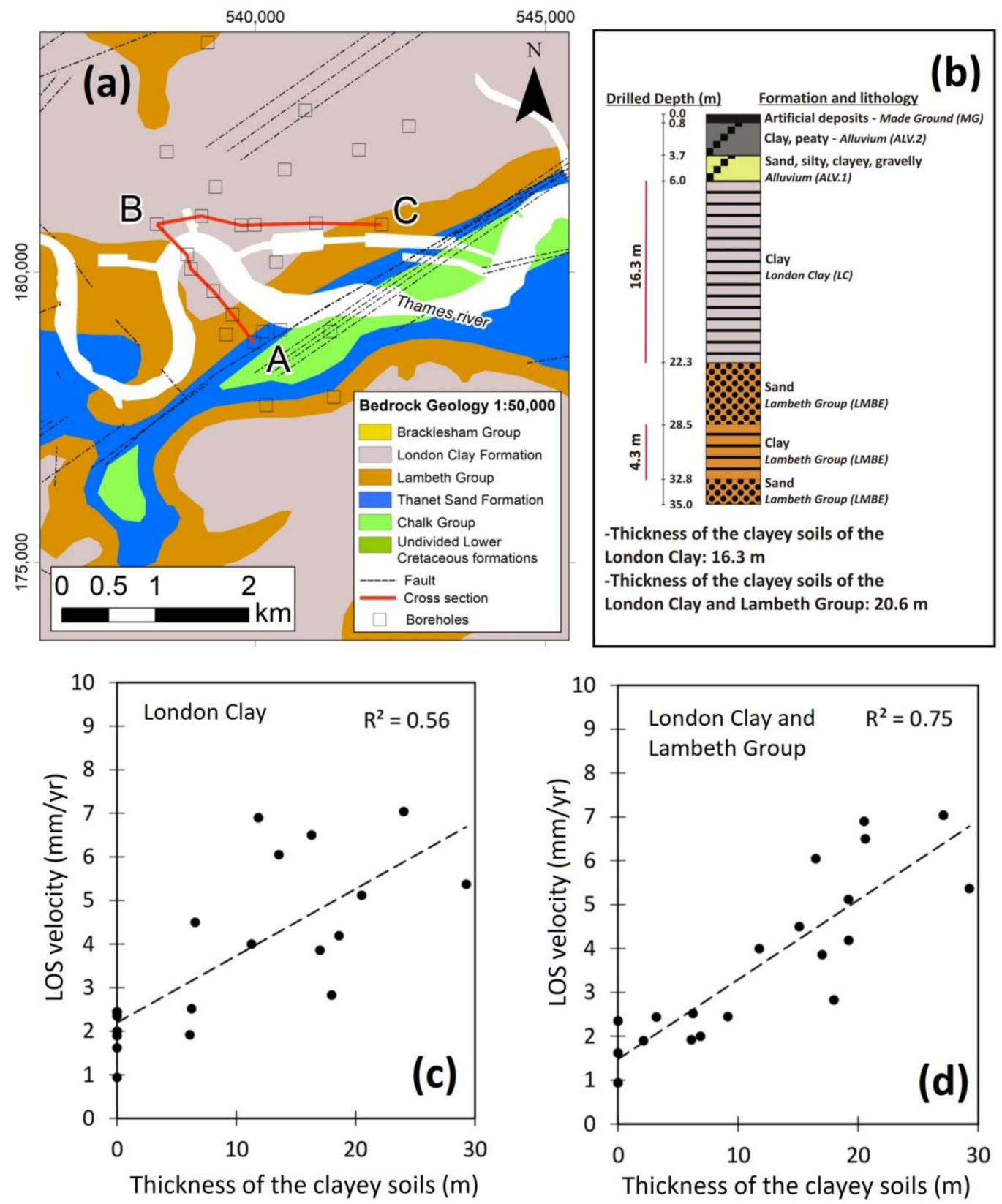

Figure 8. (a) Location of the boreholes used to estimate the thickness of the clayey soils. The cross sections (red line) are also reported; (b) Example of the procedure applied to estimate the thickness of the clayey soils of the London Clay and by computing the sum of the thickness of the clayey soils of the London Clay and Lambeth Group; (c) Comparison of the LOS velocity estimates in the period 2015-2017 with the thickness of clayey soils of the London clay using the boreholes information; (d) Comparison of the LOS velocity estimates in the period 2015-2017 with total thickness of clayey lithologies of the boreholes considering the London Clay and the Lambeth Group. Based upon the 1:50,000 bedrock geology, with the permission of the British Geological Survey. All rights reserved.

Then, the BGS geotechnical database [44] was analyzed to investigate the role of the geotechnical properties of the deposits located in the study area. A buffer of $50 \mathrm{~m}$ has been computed for each geotechnical borehole (Figure 9a) and the average LOS velocity has been extracted. Then, the LOS velocity in the buffers have been plotted versus the swelling pressure (SPRS) of these formations (Figure 9b). The values of swelling pressure represent the pressure exerted by a contained clay when absorbing water in a confined space and derive from consolidation tests performed using samples 
extracted at different depths for each borehole [44]. The analysis of the SPRS has been performed by diving the measures obtained for the alluvial of the Thames and River Terrace Deposits that represent the superficial deposits (samples carried out in the first $7 \mathrm{~m}$ ) and for the deeper formations such as the LC and LMBE (samples carried out at depth higher than $7 \mathrm{~m}$ ). It is worth noting that a direct and linear correlation between the swelling pressure and the average LOS velocity for the deeper layer is evident, while the superficial deposits do not show a linear correlation between the swelling pressure and LOS velocity which can be explained with the coarser granulometry, different mineralogy and thinner succession ( $<10 \mathrm{~m}$ on average) of the overlying material. Jones et al., 2017 [34] analyzed the swelling potential of the London Clay at different depths, and specifically: $0,-1,-2,-3,-4,-5$, $-10,-15$ and $-20 \mathrm{~m}$ across England and Wales. According to Jones et al., 2017 [34], in the study area are present potential swelling soils associated with a high Volume Change Potential (VCP). VCP is the relative change in volume of a soil to be expected with changes in soil moisture content and is manifested by shrinking and swelling of the ground [34]. The superficial deposits (up to $-5 \mathrm{~m}$ deep) are characterized by VCP in the classes $\mathrm{A}, \mathrm{B}$, and $\mathrm{C}$ that correspond to non-plastic, low and medium plasticity classes, with Ip' up to 40\% according the classification introduced by Jones et al., 2017 [34]. From $-10 \mathrm{~m}$ the VCP assumes value referred to class D according to [34], that means formations with high plasticity up to $60 \%$. Therefore, also the analysis of the plasticity index shows that the clayey layers between $10-15 \mathrm{~m}$ depth are characterized by high plasticity index and high swelling pressure and these layers could be responsible of the detected uplift.

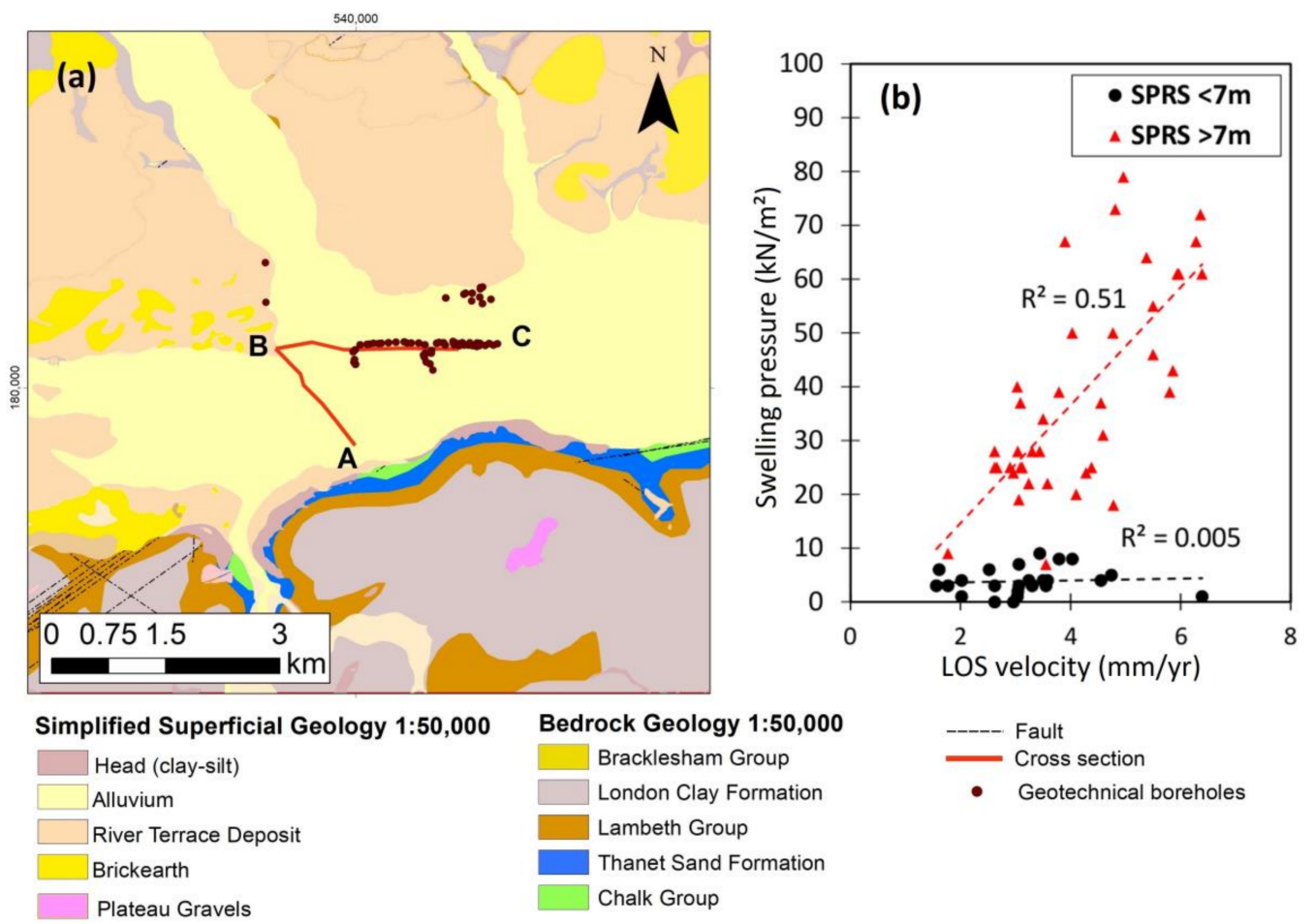

Figure 9. (a) Location of the geotechnical boreholes; (b) Comparison of the LOS velocity estimates in the period 2015-2017 with the swelling pressure of the superficial (depth lower than $7 \mathrm{~m}$ ) and deeper layers (higher than $7 \mathrm{~m}$ ). Simplified Superficial Geology of Greater London modified from the DiGMapGB50, the Digital Geological Map of Great Britain at the 1:50,000 scale and bedrock geology at the 1:50,000 scale, with the permission of the British Geological Survey. All rights reserved.

\subsubsection{Comparison between the Groundwater Level Changes and Deformation Rates}

After considering the clayey layer of the LC and partially contained in the LMBE as the predisposing factor of the uplift, the triggering factors of the occurrence of these movements in the period 2015-2017 were investigated. First, the groundwater level changes were analyzed to verify 
if the uplift is related to a groundwater rebound. Indeed, the uplift zone (Figure 10) is located in an area where the aquifer is confined by the LC and pore pressure changes could trigger ground motion. Therefore, historical ERS-1/2 and ENVISAT data were also exploited to compare the deformation rates and the piezometric level evolution in the last twenty-four years. Unfortunately, in the uplift area (Figure 10), piezometers time series provided by the Environment Agency are not available for the 1992-2016 period, but four exemplificative piezometers time series have been analyzed in proximity of the uplift area (Figure 10). It is worth noting that the use of the PSI data acquired by different sensors using different incidence angles clearly affects the capability to measure the vertical component of the displacement. More precisely, ERS-1/2 and ENVISAT with an incidence angle of $23^{\circ}$ allows the estimation of $92 \%$ of vertical displacements, while Sentinel- 1 satellites with a $34^{\circ}$ incidence angle only detect $83 \%$ of vertical displacements. Therefore, LOS velocities have been projected along the vertical direction for each dataset in order to homogenize the datasets for the comparison with the groundwater level changes (Figure 10).

Groundwater level changes between January 2015 and January 2016 reported by the Environment Agency [41] record a rise of $1 \mathrm{~m}$ in the uplift zone (Figure 10). Furthermore, by cross-comparison of the available piezometric level measurements with the deformation rates, a direct correlation is evident (Figure 10) as previously reported [28].
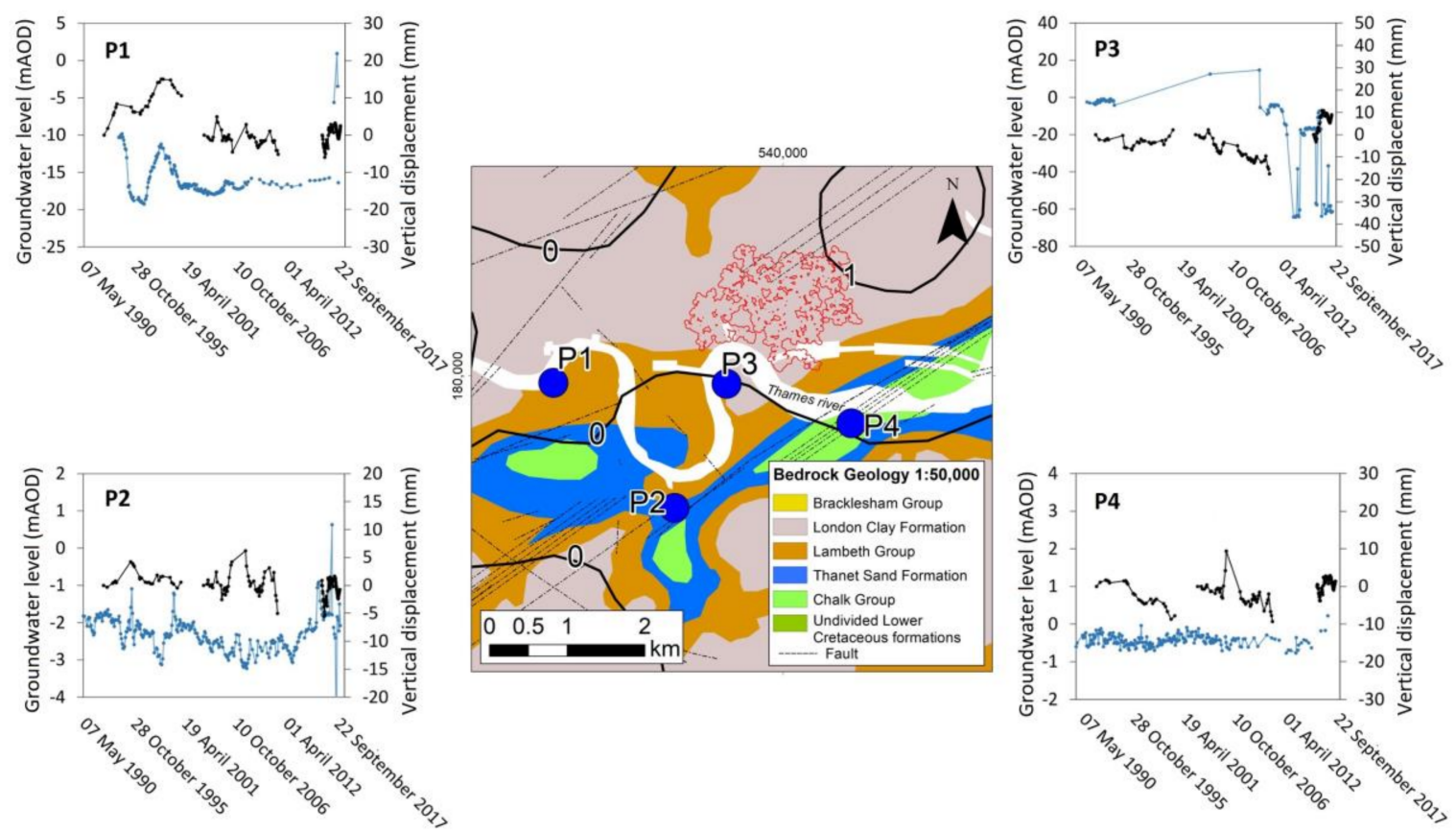

Figure 10. Cross-comparison between the deformation rates detected using ERS-1/2, ENVISAT and Sentinel-1 data and groundwater level changes. The black and the blue lines represent the vertical displacement and the groundwater level data, respectively. In the map; the black lines represent the groundwater level change (m) between January 2015 and January 2016 from [41] and the red line represents the uplift area. Based upon the 1:50,000 bedrock geology, with the permission of the British Geological Survey. Contains Environment Agency information @ Environment Agency and/or database right 2017.

\subsubsection{Comparison between Urbanization, Construction Processes and Uplift Rates}

As already mentioned in Section 1, London represents a megacity where an increasing urban development has been reached. Therefore, the role of the urbanization for the ground displacement has been investigated. Building construction could be an accelerating factor for the consolidation processes [61], whereas in this case it was verified that the uplift could be due to local groundwater 
rebound after the termination of construction processes supposing dewatering operations. Thus, the age of the building constructions has been plotted versus the LOS velocity, with the results showing that newer building corresponds to areas with the highest terrain uplift (Figure 11). Furthermore, even if newer buildings have been constructed (2000-2009), the measured LOS velocity is low (higher than -3 and lower than $3 \mathrm{~mm}$ /year), whereas in the London Clay it is not present (see the cross-section A-B in Figure 11). While uplift rates higher than $7 \mathrm{~mm} /$ year are observed where the buildings have been built up in the period 2000-2009, the uplift ranges between 3 to $7 \mathrm{~mm}$ /year where the buildings have been constructed in the period 1993-1999.

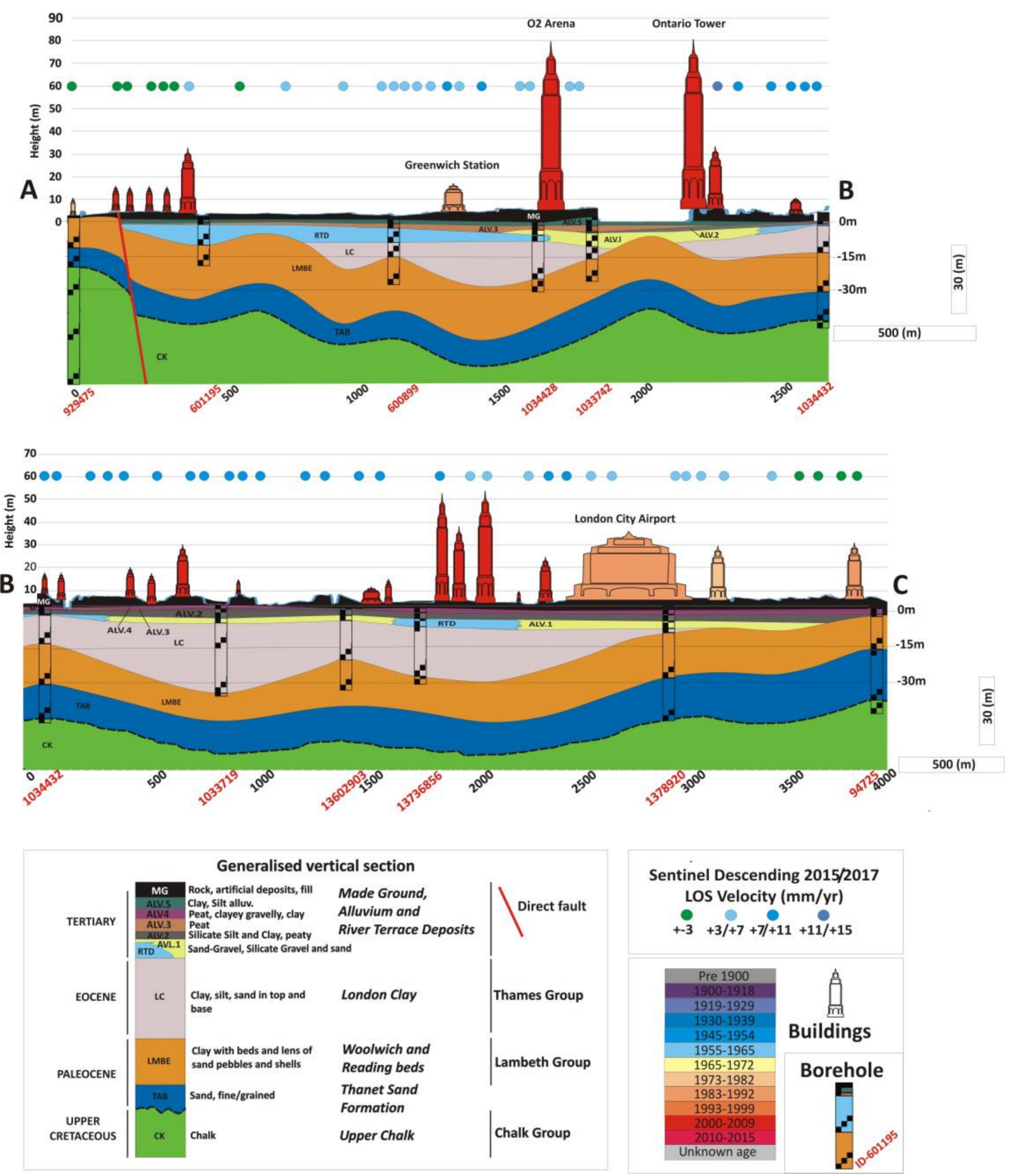

Figure 11. Cross section and buildings age. Based upon Groundhog Desktop data; with the permission of the British Geological Survey. See the location of the cross section in Figures 8 and 9.

Furthermore, the role of the engineering works for the Crossrail construction has also been assessed. Crossrail is a $42 \mathrm{~km}$ underground railway under London, running as far west as Reading in 
Berkshire and as far east as Shenfield in Essex and includes the construction of a $21 \mathrm{~km}$ of twin-bore tunnel, 10 newly built, and 30 upgraded stations up to approximately $30 \mathrm{~m}$ below street level (Figure 12). During the construction, begun in 2012, controlled dewatering was performed at some stations in order to guarantee ground stability during the excavation process [62]. The dewatering operations started from 11 August 2008 for works at Canary Wharf Station (Figure 12) and ceased in August 2015, with a substantial reduction of pumping at Limmo (Figure 12). All dewatering operations were completed on 14 March 2016. Simultaneous dewatering was undertaken at multiple Crossrail sites. During the dewatering process the ground water level was monitored. More precisely, the dewatering was performed in the deep aquifer (Chalk-Thanet Sand) and in the shallow aquifer (Made Ground and River Terrace Deposits). In the intermediate aquifer (Lambeth Group-Harwich Formation), de-pressuration works were performed to reduce the water pressures, rather than removing the water itself. Therefore, the works connected with the Crossrail Project mainly affected the deep aquifer and did not affect the intermediate and shallow aquifers $[62,63]$.
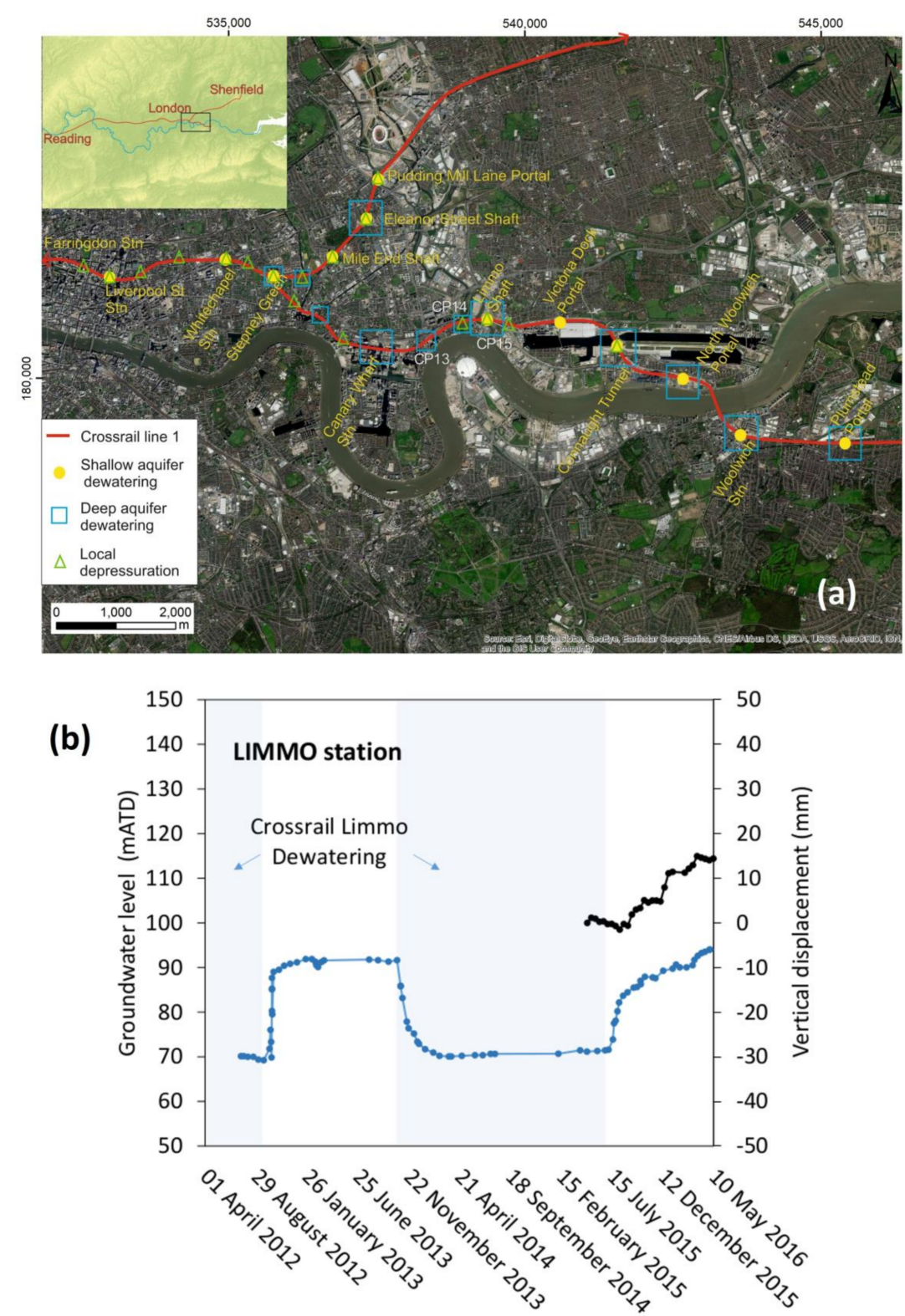

Figure 12. (a) Location of the Crossrail line 1 and the dewatering sites. (b) Cross-comparison of the average TS obtained using the Sentinel- 1 data in a buffer zone of $50 \mathrm{~m}$ from Limmo shaft and the groundwater level changes measured at Limmo station. Dewatering periods are also reported. 
The uplift area is located in the Crossrail worksite named the Limmo Shaft, where a $40 \mathrm{~m}$ deep shaft was required for the construction of $8.3 \mathrm{~km}$ of tunnel from the Limmo Peninsula to Farringdon (Figure 12a). In this area, the pumping started on the 4 November 2013 to support dewatering works CP13 and CP14 (Figure 12a) and was completed on the 14 March 2016 (Figure 12b). Dewatering of the major aquifer was performed, including the deep aquifer, in the Thanet Sand and Chalk strata. After the completion of the dewatering, groundwater recovery was observed from August 2015 to May 2016. The uplift rates detected using the Sentinel-1 data were compared with the groundwater level changes measured at Limmo station (Figure 12b). The results give insight about the direct correlation between the groundwater rebound after the completion of the dewatering procedure at Limmo. Indeed, the breaks in the TS date detected at August 2015 and May August 2016 represents the termination of the dewatering procedure and the end of the groundwater rebound, respectively. The groundwater rebound of around $20 \mathrm{~m}$ corresponds to about $15 \mathrm{~mm}$ of uplift. Moreover, a delay time of about 1 month has been detected between the beginning of the groundwater level recovery and the uplift trend.

\section{Discussion}

This work introduces a methodology for the geological interpretation of PSI data for the detection and characterization of uplift trends in an urban area. The systematic and reproducible procedure has been developed and tested using the new and freely available Sentinel-1 SAR data acquired over the London basin. The procedure improves the management and interpretation of dense time series as acquired by Sentinel-1 sensors and gives insight into the possibility of new applications of the recent sensors to monitor the movements during construction process and the effects after the termination of the engineering works.

From the geological point of view, the uplift zone insists on the depocenter of the syncline of the London Basin and it is bounded by faults in the southern area. The analysis of the geotechnical parameters has highlighted a high value of swelling pressure for the clayey soils of the London Clay and Lambeth Group (bedrock formations), and a low value for the alluvium soil and River Terrace Deposits present in the superficial deposits, confirming that bedrock formations, when wetted, have a great potential of volume change which can be responsible for the uplift. Indeed, in the study area, the piezometric level rose by $1 \mathrm{~m}$ in the period 2015-2016.

In the Tower Hamlets area (Figure 1), several large buildings built after the 2000s are also present. To construct their foundations the piezometric level was probably lowered below the swelling formations. Following the construction of the foundations the subsequent rise of the groundwater may have caused the swelling of the clayey formations. Considering that dewatering operations probably were implemented in the uplift area to proceed with construction works; the subsequent groundwater rebound after the completion of the works may have caused the swelling of the clayey formations. From the analysis of the geological, hydrogeological, structural, and anthropogenic factors it is possible to hypothesize that the uplift was caused by the rise of the piezometric level in this particular geological contest.

It is worth noting that the groundwater rebound due to the completion of the dewatering procedures for the Crossrail construction is correlated with the non-linear uplift trend detected using the Sentinel-1 data. The dewatering activities in the shallow aquifer were performed by local pumping or sump flows of the deposits enclosed within impermeable retaining walls and they did not generate effects on this aquifer outside the retaining walls [62]. Whereas, the dewatering operations of the deep aquifer generated temporary effects in the groundwater level [63]. Indeed, the maximum planned abstraction triggers; in January 2014, a drawdown cone measuring $5.9 \mathrm{~km} \times 7 \mathrm{~km}$ in plan, with a maximum drawdown in the Chalk of about $35 \mathrm{~m}$ at the Canary Warf [62]. After the termination of Crossrail dewatering, the drawdown cone induced by Crossrail was dissipated and the groundwater level gradually recovered. Therefore, it is reasonable that the highest value of uplift occurs in an area where the recovery is fastest because the cone depression was greatest. 
Therefore; the full groundwater level recovery that has been achieved at Limmo could be the cause of the uplift area, whereas in the Canary Wharf, the deep central cone still existed in 2016 because the dewatering was still ongoing. Thus, an uplift trend is also expected in the proximity of the Canary Wharf after the groundwater recovery in the following years.

\section{Conclusions}

In this work a methodology to detect and characterize uplift trends in urban areas using new satellite SAR sensors such as Sentinel-1 data is presented. The principal novelty of the proposed procedure is the full exploitation of the displacement time series and the average velocity obtained by the PSI technique. The methodology represents a systematic and reproducible approach to investigate uplift phenomena in urban areas. The proposed methodology consists of three phases:

1. Displacement time series and average velocity accuracy assessment: check of the systematic errors that could affect the whole dataset and local validation with external data such as GNSS measurements.

2. Displacement time series analysis: two approaches have been implemented, such as a statistical procedure to find the PC of TS and an automatic classification tool for TS based on statistical tests.

3. Mechanism recognition: cross-comparison between the uplift rates and external data (such as geological, geotechnical, hydrogeological, urbanization and construction processes data) in order to interpret the predisposing and triggering factors of the phenomena.

The methodology was tested in London, which is a representative high-urbanized area, using the Sentinel-1 data covering the period from 2015 to 2017. The results confirm its ability for the definition of the extension and rates of uplift phenomena and for the characterization of the phenomena. The results reveal that an area of about $5 \mathrm{~km}^{2}$ localized between the $\mathrm{O} 2$ arena and the London City Airport has experienced an average uplift rates of $7 \mathrm{~mm}$ /year and a maximum value of $18 \mathrm{~mm}$ /year in the period from May 2015 to March 2017. The analysis of the displacement time series indicates a non-linear trend of the uplift area characterized by an acceleration during the period from August 2015 to May-August 2016, and decreasing uplift rates from 2017. The comparison between the spatio-temporal evolution of the movements and the predisposing and triggering factors gives insight about the correlation between the uplift trends and the thickness of the clayey soils within the LC and LMBE. Furthermore, the analysis of the geotechnical properties of the LC shows that the soils localized in the uplift area have high volume change potential between 10 to $15 \mathrm{~m}$ in depth. The groundwater level change of the uplift area is about of $1 \mathrm{~m}$ in the period 2015-2016. The uplift triggered by the groundwater rebound occurs in a peculiar geological context, such as the depocenter of the syncline of the London Basin, where the maximum thickness of clayey soils is reached, and the aquifer is characterized by confined conditions. Additionally, the role of recent construction has been investigated in detail. Indeed, uplift rates higher than $7 \mathrm{~mm}$ /year are observed where the buildings have been built up in the period 2000-2009 and the uplift ranges between 3 to $7 \mathrm{~mm}$ /year where the buildings have been constructed in the period 1993-1999.

Furthermore, the role of the engineering works for the Crossrail construction has also been assessed and the results reveal that the breaks in the TS coincides with the termination of the dewatering procedure and the end of the groundwater rebound, respectively.

In the era of big data with multiple SAR systems coming into service, our methodology has proven to be appropriate and efficient to leverage large volumes of heterogeneous data and is easily applicable in others urban areas. The findings in this work confirmed that these systems can support the knowledge of the effects after the termination of dewatering works such as for the Crossrail project in London.

The approach contributed to understanding the uplift phenomenon in London due to the interaction of anthropic activities and natural predisposing factors. Overall this work contributes to an increased understanding of the ground motion response after dewatering operations and the 
analysis could play a significant role on evaluating the induced displacements by future construction processes in other similar geological settings.

Acknowledgments: Groundwater level data for the London Basin were provided by the Environment Agency (License No. NR45879; non-commercial use), and the ERS and ENVISAT PS data via the EC FP7 PanGeo project. Sentinel-1 data were provided by the European Space Agency (ESA). This paper is published with permission of the Executive Director of BGS; NERC. The authors would like to thank the editor and three anonymous referees for their valuable comments and suggestions to improve the quality of the paper.

Author Contributions: Roberta Bonì wrote the paper and she conceived and designed the methodology to detect and characterize uplift phenomena in urban areas using Sentinel-1 data in the framework of the project entitled "Advanced detection, interpretation and modelling of ground motion areas (A-GMA)" at the University of Pavia. Alberto Bosino analyzed the PSI and geological data in the framework of the Erasmus + Traineeship program at the British Geological Survey (BGS) in March-May 2017. Claudia Meisina provided guidance and support throughout the research process to develop the methodology and she provided support for the analysis of the geotechnical data. Alessandro Novellino and Luke Bateson supervised Alberto Bosino during his visit at BGS and supported the analysis of the PSI and geological data. Alessandro Novellino provided guidance for the collection and analysis of the geological; groundwater level and buildings database. Claudia Meisina and Roberta Bonì supervised Alberto Bosino in the framework of his master thesis. Harry McCormack processed and analyzed ERS-1/2, ENVISAT and Sentinel-1 data for the London Basin. All authors co-wrote and reviewed the manuscript. The authors would like to acknowledge Lee Jones and Ricky Terrington from BGS for their valuable suggestions to improve the quality of the paper. Alessandro Novellino and Luke Bateson publish with the permission of the Executive Director of BGS.

Conflicts of Interest: The authors declare no conflict of interest.

\section{References}

1. Galloway, D.L.; Jones, D.R.; Ingebritsen, S.E. Land Subsidence in the United States: U.S. Geological Survey; Circular 1182; U.S. Geological Survey: Reston, VA, USA, 1999; p. 177.

2. Chaussard, E.; Milillo, P.; Bürgmann, R.; Perissin, D.; Fielding, E.J.; Baker, B. Remote Sensing of Ground Deformation for Monitoring Groundwater Management Practices: Application to the Santa Clara Valley During the 2012-2015 California Drought. J. Geophys. Res. Solid Earth 2017, 122, 8566-8582. [CrossRef]

3. Deffontaines, B.; Kaveh, F.; Fruneau, B.; Arnaud, A.; Duro, J. Monitoring Swelling Soils in Eastern Paris (France) through DinSAR and PSI Interferometry: A Synthesis. In Engineering Geology for Society and Territory; Lollino, G., Manconi, A., Clague, J., Shan, W., Chiarle, M., Eds.; Springer International Publishing: Cham, Switzerland, 2015; Volume 5, pp. 195-202, ISBN 978-3-319-09048-1.

4. Amelung, F.; Gallowey, D.L.; Bell, J.; Zebker, H.; Laczniak, R.J. Sensing the ups and downs of Las Vegas: InSAR reveals structural control of land subsidence and aquifer-system deformation. Geology 1999, 27, 483-486. [CrossRef]

5. Bateson, L.; Cigna, F.; Boon, D.; Sowter, A. The application of the Intermittent SBAS (ISBAS) InSAR method to the South Wales Coalfield, UK. Int. J. Appl. Earth Obs. Geoinf. 2015, 34, 249-257. [CrossRef]

6. Gee, D.; Bateson, L.; Sowter, A.; Grebby, S.; Novellino, A.; Cigna, F.; Marsh, S.; Banton, C.; Wyatt, L. Ground motion in areas of abandoned mining: Application of the intermittent SBAS (ISBAS) to the Northumberland and Durham coalfield, UK. Geosciences 2017, 7, 85. [CrossRef]

7. Johnston, D.; Potter, H.; Jones, C.; Rolley, S.; Watson, I.; Pritchard, J. Environmental Agency Report. In Abandoned Mines and the Water Environment; Environment Agency: Bristol, UK, 2008.

8. Brake, B.T.; Hanssen, R.F.; Van der Ploeg, M.J.; De Rooij, G.H. Satellite-based radar interferometry to estimate large-scale soil water depletion from clay shrinkage: Possibilities and limitations. Vadose Zone J. 2013, 12. [CrossRef]

9. Kurka, M.; Gutjahr, K.H. Observation of Expansive Clay Movement with DInSAR. G. In Engineering Geology for Society and Territory; Lollino, G., Manconi, A., Clague, J., Shan, W., Chiarle, M., Eds.; Springer International Publishing: Cham, Switzerland, 2015; Volume 5, pp. 151-154, ISBN 978-3-319-09048-1.

10. Association of British Insurers. Subsidence-Dealing with the Problem. [Cited 3 August 2006]. 2006. Available online: http:/ / www.abi.org.uk (accessed on 12 November 2017).

11. Ferretti, A.; Prati, C.; Rocca, F. Permanent scatterers in SAR interferometry. IEEE Trans. Geosci. Remote Sens. 2001, 39, 8-20. [CrossRef] 
12. Fornaro, G.; Reale, D.; Serafino, F. Four-dimensional SAR imaging for height estimation and monitoring of single and double scatterers. IEEE Trans. Geosci. Remote Sens. 2009, 47, 212-237. [CrossRef]

13. Crosetto, M.; Monserrat, O.; Cuevas-González, M.; Devanthéry, N.; Crippa, B. Persistent scatterer interferometry: A review. ISPRS J. Photogramm. Remote Sens. 2016, 115, 78-89. [CrossRef]

14. Peduto, D.; Huber, M.; Speranza, G.; van Ruijven, J.; Cascini, L. DInSAR data assimilation for settlement prediction: Case study of a railway embankment in The Netherlands. Can. Geotech. J. 2017, 54, 502-517. [CrossRef]

15. Confuorto, P.; Di Martire, D.; Centolanza, G.; Iglesias, R.; Mallorqui, J.J.; Novellino, A.; Plank, S.; Ramondini, M.; Thuro, K.; Calcaterra, D. Post-failure evolution analysis of a rainfall-triggered landslide by multi-temporal interferometry SAR approaches integrated with geotechnical analysis. Remote Sens. Environ. 2017, 188, 51-72. [CrossRef]

16. Meisina, C.; Zucca, F.; Fossati, D.; Ceriani, M.; Allievi, J. Ground deformation monitoring by using the permanent scatterers technique: The example of the Oltrepo Pavese (Lombardia, Italy). Eng. Geol. 2006, 88, 240-259. [CrossRef]

17. Huang, Q.; Crosetto, M.; Monserrat, O.; Crippa, B. Displacement monitoring and modelling of a high-speed railway bridge using C-band Sentinel-1 data. ISPRS J. Photogramm. Remote Sens. 2017, 128, 204-211. [CrossRef]

18. North, M.; Farewell, T.; Hallett, S.; Bertelle, A. Monitoring the Response of Roads and Railways to Seasonal Soil Movement with Persistent Scatterers Interferometry over Six UK Sites. Remote Sens. 2017, 9, 922. [CrossRef]

19. Lan, H.; Li, L.; Liu, H.; Yang, Z. Complex Urban Infrastructure Deformation Monitoring Using High Resolution PSI. IEEE J. Sel. Top. Appl. Earth Obs. Remote Sens. 2012, 5, 643-651. [CrossRef]

20. Tomás, R.; Cano, M.; Garcia-Barba, J.; Vicente, F.; Herrera, G.; Lopez-Sanchez, J.M.; Mallorquí, J.J. Monitoring an earthfill dam using differential SAR interferometry: La Pedrera dam, Alicante, Spain. Eng. Geol. 2013, 157, 21-32. [CrossRef]

21. Milillo, P.; Perissin, D.; Salzer, J.T.; Lundgren, P.; Lacava, G.; Milillo, G.; Serio, C. Monitoring dam structural health from space: Insights from novel InSAR techniques and multi-parametric modeling applied to the Pertusillo dam Basilicata, Italy. Int. J. Appl. Earth Obs. Geoinf. 2016, 52, 221-229. [CrossRef]

22. Strozzi, T.; Delaloye, R.; Poffet, D.; Hansmann, J.; Loew, S. Surface subsidence and uplift above a headrace tunnel in metamorphic basement rocks of the Swiss Alps as detected by satellite SAR interferometry. Remote Sens. Environ. 2011, 115, 1353-1360. [CrossRef]

23. Royse, K.R.; de Freitas, M.; Burgess, W.G.; Cosgrove, J.; Ghail, R.C.; Gibbard, P.; King, C.; Lawrence, U.; Mortimore, R.N.; Owenj, H.; et al. Geology of London, UK. Proc. Geol. Assoc. 2012, 123, 22-45. [CrossRef]

24. Bricker, S.H.; Banks, V.J.; Galik, G.; Tapete, D.; Jones, R. Accounting for groundwater in future city visions. Land Use Policy 2017, 69, 618-630. [CrossRef]

25. Aldiss, D.; Burke, H.; Chacksfield, B.; Bingley, R.; Teferle, N.; Williams, S.; Blackman, D.; Burren, R.; Press, N. Geological interpretation of current subsidence and uplift in the London area; UK; as shown by high precision satellite-based surveying. Proc. Geol. Assoc. 2014, 125, 1-13. [CrossRef]

26. Cigna, F.; Jordan, H.; Bateson, L.; McCormack, H.; Roberts, C. Natural and anthropogenic geohazards in greater London observed from geological and ERS-1/2 and ENVISAT persistent scatterers ground motion data: Results from the EC FP7-SPACE PanGeo Project. Pure Appl. Geophys. 2015, 172, 2965-2995. [CrossRef]

27. Bateson, L.B.; Barkwith, A.K.A.P.; Hughes, A.G.; Aldiss, D.T. Terrafirma: London H-3 Modelled Product: Comparison of PS Data with the Results of a Groundwater Abstraction Related Subsidence Model; British Geological Survey Commissioned Report; OR/09/032; British Geological Survey: Keyworth, Nottingham, UK, 2009; 47p.

28. Bonì, R.; Cigna, F.; Bricker, S.; Meisina, C.; McCormack, H. Characterisation of hydraulic head changes and aquifer properties in the London Basin using Persistent Scatterer Interferometry ground motion data. J. Hydrol. 2016, 540, 835-849. [CrossRef]

29. Milillo, P.; Giardina, G.; DeJong, M.J.; Perissin, D.; Milillo, G. Multi-Temporal InSAR Structural Damage Assessment: The London Crossrail Case Study. Remote Sens. 2018, 10, 287. [CrossRef]

30. Bonì, R.; Pilla, G.; Meisina, C. Methodology for detection and interpretation of ground motion areas with the A-DInSAR time series analysis. Remote Sens. 2016, 8, 686. 
31. Sumbler, M.G. British Regional Geology: London and the Thames Valley, 4th ed.; HMSO for the British Geological Survey: London, UK, 1996.

32. Ellison, R.A.; Woods, M.A.; Allen, D.J.; Forster, A.; Pharaoh, T.C.; King, C. Geology of London: Special Memoir for 1:50,000 Geological Sheets 256 (North London); 257 (Romford); 270 (South London); and 271 (Dartford) (England and Wales); British Geological Survey: London, UK, 2004.

33. Sellwood, B.W.; Sladen, C.P. Mesozoic \& Tertiary argillaceous units: Distribution and composition. Q. J. Eng. Geol. Hydrogeol. 1981, 14, 263-275.

34. Jones, L.D.; Terrington, R. Methods for Modelling the 3D Volume Change Potential of UK Clay Soils; British Geological Survey Research Report; RR/17/008; British Geological Survey: London, UK, 2017; 57p.

35. Jones, L.D.; Terrington, R. Modelling volume change potential in the London Clay. Q. J. Eng. Geol. Hydrogeol. 2011, 44, 109-122. [CrossRef]

36. Barker, J.A. Transport in fractured rock. In Applied Groundwater Hydrology; Downing, R.A., Wilkinson, W.B., Eds.; Claredon Press: Oxford, UK, 1991; pp. 199-216.

37. Price, M. Fluid flow in the Chalk of England. In Fluid Flow in Sedimentary Basins and Aquifers; Goff, J.C., Williams, B.P.J., Eds.; Geological Society London Special Publications: London, UK, 1987; Volume 34, pp. 141-156.

38. Price, M.; Downing, R.A.; Edmunds, W.M. The Chalk as an aquifer. In The Hydrogeology of the Chalk of North-West Europe; Downing, R.A., Price, M., Jones, G.P., Eds.; Clarendon Press: Oxford, UK, 1993; pp. 14-34.

39. Bloomfield, J.P.; Brewerton, L.J.; Allen, D.J. Regional trends in matrix porosity and dry density of the chalk of England. Q. J. Eng. Geol. 1995, 28, S-131-S-142. [CrossRef]

40. Allen, D.J.; Brewerton, L.J.; Coleby, L.M.; Gibbs, B.R.; Lewis, M.A.; MacDonald, A.M.; Wagstaff, S.J.; Williams, A.T. The Physical Properties of Major Aquifers in England and Wales; British Geological Survey Technical Report WD/97/34; British Geological Survey: London, UK, 1997.

41. Environment Agency. Management of the London Basin Chalk Aquifer; Status Report 2016; Environment Agency Report; Environment Agency: Bristol, UK, 2016.

42. Environment Agency. Management of the London Basin Chalk Aquifer; Status Report 2017; Environment Agency Report; Environment Agency: Bristol, UK, 2017. Available online: https://www.gov.uk/government/ publications/london-basin-chalk-aquifer-annual-status-report (accessed on 13 April 2018).

43. Werner, C.; Wegmüller, U.; Wiesmann, A.; Strozzi, T. Interferometric point target analysis with JERS-1 L-band SAR data. In Proceedings of the IEEE International Geoscience and Remote Sensing Symposium 2003, IGARSS 2003, Toulouse, France, 21-25 July 2003; Volume 7, pp. 4359-4361.

44. Self, S.J.; Entwisle, D.C.; Northmore, K.J. The Structure and Operation of the BGS National Geotechnical Properties Database Version 2; British Geological Survey Internal Report IR/12/056; British Geological Survey: London, UK, 2012.

45. Jones, L. User Guide for the 3D Shrink-Swell (GeoSure Extra) Dataset; British Geological Survey Open Report; OR/16/043; British Geological Survey: London, UK, 2016; 14p.

46. Building Research Establishment (BRE). Low-Rise Buildings on Shrinkable Clay Soils; BRE Digest; Construction Research Communications: London, UK, 1993; Volume 240-242.

47. Building Heights in England. Available online: http:/ / buildingheights.emu-analytics.net (accessed on 12 November 2017).

48. Consumer Data Research Centre. Dwellings: Modal Age. Available online: https://maps.cdrc.ac.uk/ (accessed on 12 November 2017).

49. Ding, X.L.; Li, Z.W.; Zhu, J.J.; Feng, G.C.; Long, J.P. Atmospheric effects on InSAR measurements and their mitigation. Sensors 2008, 8, 5426-5448. [CrossRef] [PubMed]

50. Crosetto, M.; Monserrat, O.; Iglesias, R.; Crippa, B. Persistent Scatterer Interferometry. Photogram. Eng. Remote Sens. 2010, 76, 1061-1069. [CrossRef]

51. Notti, D.; Calò, F.; Cigna, F.; Manunta, M.; Herrera, G.; Berti, M.; Meisina, C.; Tapete, D.; Zucca, F. A user-oriented methodology for DInSAR time series analysis and interpretation: Landslides and subsidence case studies. Pure Appl. Geophys. 2015, 172, 3081-3105. [CrossRef]

52. Cigna, F.; Tapete, D.; Casagli, N. Semi-automated extraction of Deviation Indexes (DI) from satellite Persistent Scatterers time series: Tests on sedimentary volcanism and tectonically-induced motions. Nonlinear Processes Geophys. 2012, 19, 643-655. [CrossRef] 
53. Chaussard, E.; Bürgmann, R.; Shirzaei, M.; Fielding, E.J.; Baker, B. Predictability of hydraulic head changes and characterization of aquifer-system and fault properties from InSAR-derived ground deformation. J. Geophys. Res. Solid Earth 2014, 119, 6572-6590. [CrossRef]

54. Berti, M.; Corsini, A.; Franceschini, S.; Iannacone, J.P. Automated classification of Persistent Scatterers Interferometry time series. Nat. Hazards Earth Syst. Sci. 2013, 13, 1945-1958. [CrossRef]

55. Wegmüller, U.; Werner, C.; Wiesmann, A.; Strozzi, T.; Kourkouli, P.; Frey, O. Time-series analysis of Sentinel-1 interferometric wide swath data: Techniques and challenges. In Proceedings of the 2016 IEEE International Geoscience and Remote Sensing Symposium (IGARSS), Beijing, China, 10-15 July 2016; pp. 3898-3901.

56. Casu, F.; Manzo, M.; Lanari, R. A quantitative assessment of the SBAS algorithm performance for surface deformation retrieval from DInSAR data. Remote Sens. Environ. 2006, 102, 195-210. [CrossRef]

57. Fornaro, G.; Reale, D.; Verde, S. Bridge Thermal Dilation Monitoring With Millimeter Sensitivity via Multidimensional SAR Imaging. IEEE Geosci. Remote Sens. Lett. 2013, 10, 677-681. [CrossRef]

58. Nicodemo, G.; Peduto, D.; Ferlisi, S.; Maccabiani, J. Investigating building settlements via very high resolution SAR sensors. In 2017 Life-cycle of Engineering Systems: Emphasis on Sustainable Civil Infrastructure; Bakker, J., Frangopol, D.M., van Breugel, K., Eds.; Taylor \& Francis Group: London, UK, 2016; pp. 2256-2263.

59. Bonì, R.; Meisina, C.; Cigna, F.; Herrera, G.; Notti, D.; Bricker, S.; McCormack, H.; Tomás, R.; Béjar-Pizarro, M.; Mulas, J.; et al. Exploitation of satellite A-DInSAR time series for detection, characterization and modelling of land subsidence. Geosciences 2017, 7, 25. [CrossRef]

60. Richman, M.B. Rotation of principal components. J. Climatol. 1986, 6, 293-335. [CrossRef]

61. Solari, L.; Ciampalini, A.; Raspini, F.; Bianchini, S.; Moretti, S. PSInSAR Analysis in the Pisa Urban Area (Italy): A Case Study of Subsidence Related to Stratigraphical Factors and Urbanization. Remote Sens. 2016, 8, 120. [CrossRef]

62. Crossrail, Crossrail Project Dewatering Works-Close-out Report. 2016. Available online: https:// learninglegacy.crossrail.co.uk/wp-content/uploads/2017/01/7A-026_1-Dewatering-Close-out-report.pdf (accessed on 12 November 2017).

63. Black, M. Crossrail project: Managing geotechnical risk on London's Elizabeth line. In Proceedings of the Institution of Civil Engineers-Civil Engineering; Thomas Telford Ltd.: London, UK, 2017; Volume 170, pp. 23-30.

(C) 2018 by the authors. Licensee MDPI, Basel, Switzerland. This article is an open access article distributed under the terms and conditions of the Creative Commons Attribution (CC BY) license (http:/ / creativecommons.org/licenses/by/4.0/). 